\title{
Progress in Microbial Ecology in Ice-Covered Seas
}

\author{
Tobias R. Vonnahme, Ulrike Dietrich, \\ and Brandon T. Hassett
}

\begin{abstract}
Sea ice seasonally covers $10 \%$ of the earth's oceans and shapes global ocean chemistry. The unique physical processes associated with sea ice growth and development shape the associated biological diversity and ecosystem function. Microbes make up the base of all marine food webs and the overwhelming majority of biomass in the sea ice ecosystem. Despite their biomass, microbial processes are not fully integrated into marine ecosystem models. Recent applications of novel molecular biology technologies to studies of marine ecology have elucidated numerous microbial-mediated processes interfaced by previously unknown organisms and processes. These discoveries are yielding more in-depth studies on the relevance of mixotrophy, the ecology of fungi, and the interplay between major microbial clades. In ecosystem studies, the basis of the food web is frequently neglected even though the accessibility of energy, recycling of nutrients, and parasitism are crucial factors shaping the environment for grazers and higher trophic levels. In this review, we focus on the species composition, abundance, and functions of microalgae, bacteria, archaea, fungi, and viruses in the sea ice-covered seas throughout the year. A strong emphasis will be put on advances in molecular methods that empower scientists to further investigate microorganisms in more detail. Since microbes make up the majority of all oceanic biomass, we believe that it is impossible to accurately forecast the biological fate of polar marine ecosystems without placing a proportional emphasis on microbes relative to their biomass.
\end{abstract}

\section{Keywords}

Mixotrophy $\cdot$ Autotrophy $\cdot$ Heterotrophy $\cdot$ Omics $\cdot$ Fungi

T. R. Vonnahme $(\bowtie) \cdot$ U. Dietrich $(\bowtie) \cdot$ B. T. Hassett UiT- The Arctic University of Norway, Troms $\emptyset$, Norway e-mail: tobias.vonnahme@uit.no; Ulrike.dietrich@uit.no

\subsection{Introduction}

Sea ice seasonally covers approximately $10 \%$ of the global ocean surface and is responsible for altering global ocean chemistry. The main ice-covered marine ecosystems are found in the Arctic Ocean, the Southern Ocean, and the Baltic Sea. Within the polar marine ecosystems, sea ice formation and subsequent coverage influence light transmittance that seasonally governs under-ice primary production and the associated heterotrophic biological community. Specifically, sea ice can support $50 \%$ of total primary productivity in permanently ice-covered ecosystems (Gosselin et al. 1997; Fernández-Méndez et al. 2015) and constitutes a habitat and feeding ground for various organisms. It provides microhabitats for microalgae, chemoautotrophic and heterotrophic bacteria, archaea, viruses, fungi, and multicellular organisms (Bluhm et al. 2018) that inhabit the hypersaline brine channels (Hunt et al. 2016). The sea ice habitat is characterized by strong gradients in temperature, salinity, nutrients, and light. The small-scale spatial distribution of sea ice-associated (sympagic) biota is determined to a large extent by these physical properties (Krembs et al. 2011). Organisms within the brine channels are exposed to extreme temperatures from $0{ }^{\circ} \mathrm{C}$ in summer to below $-15^{\circ} \mathrm{C}$ in winter with associated brine salinities ranging from 0 to over 200 (Gradinger 2001). Most of the biomass within brine channels is localized near the warmer ice-water interface, where temperatures are about $-1.8{ }^{\circ} \mathrm{C}$, the brine-volume fraction is greatest, and a continuous exchange of nutrients from the water below takes place.

The two major ice types found in polar environments provide different habitat characteristics (e.g., thickness, ice bulk salinities, age, and albedo), relevant for the associated biological processes (Weeks and Ackley 1986). Multiyear ice (MYI) persists at least one melting season, whereas first-year ice (FYI) follows a seasonal pattern of ice formation and melt. On average, the surface salinity of FYI is typically around 10-12, whereas MYI typically has surface salinities 
that approach 0 (Weeks and Ackley 1986). FYI is often structurally less complex, characterized by greater light penetration through the ice that is prone to an earlier onset of seasonal melt (Moline et al. 2008). Contrasting studies between FYI and MYI indicate that FYI hosts a higher number of organisms, but a less rich microbial community. Changes within the ice biological system might have cascading effects on the ice-associated ecosystem (Secretariat of Arctic Council 2017).

The open water in sea ice-covered seas is a special system in itself. At the marginal ice zone or in open leads, a system with high levels of light and nutrients may support ice edge phytoplankton blooms dominated by different species compared to sea ice (Assmy et al. 2017). With climate change, these areas are expected to increase, changing the microbial community structure in sea-ice covered seas (Oziel et al. 2017). The consequences for higher trophic levels and carbon export are a topic of recent studies. In the Arctic and Antarctic, a large part of the ocean is ice-free during the polar night. The absence of light challenges the pelagic microbial food web due to a lack of photosynthetic primary production. Nevertheless, microbes have been found to be active throughout the polar night and different biogeochemical cycles may be dominant (Zhang et al. 2003; Berge et al. 2015; Nguyen et al. 2015).

The polar marine environment is in a state of rapid transition with tremendous changes in the abiotic environment. In the Arctic Ocean, air and surface-layer temperatures are increasing faster than the global average (Serreze and Francis 2006; Holding et al. 2015) and is driving the replacement of MYI with thinner FYI (Maslanik et al. 2011; Perovich et al. 2014; Barber et al. 2015). This replacement has contributed to an earlier onset of seasonal ice melt, an increased duration of ice melt (Stroeve et al. 2014), and persistent open water conditions in the seasonal ice zone (Lange et al. 2016). A strong reduction in overall Arctic sea ice extent occurred over the last two decades, with the lowest summer minimum ice extent in $2012\left(3.61 \times 10^{6} \mathrm{~km}^{2}\right)$, which had been $18 \%$ below the previous low of 2007 (Beitler 2012). In contrast to the Arctic, the Antarctic is characterized by a large extent of seasonally forming ice that grows from $4 \times 10^{6} \mathrm{~km}^{2}$ in summer to approximately $19 \times 10^{6} \mathrm{~km}^{2}$ in late winter (Cavalieri et al. 1999). Specifically during autumn, the surface of the ocean surrounding the Antarctic continent begins to freeze, forming sea ice of about $0.4 \mathrm{~m}$ thickness (up to $1 \mathrm{~m}$; Worby et al. 2001). Overall, the ice extent in the Antarctic has been much less impacted compared to the Arctic. In the Antarctic Peninsula and Bellinghausen Sea region, the ice-free summer season is extended by three months, whereas in the western Ross Sea region, the ice-free season is shortened by two months (Lange et al. 2016). Due to strong wind events, large quantities of heat are extracted from the surface ocean, facilitating rapid formation of frazil ice (Eicken 2003).
The Baltic Sea is one of the world's largest brackish water basins with a surface area of $422,000 \mathrm{~km}^{2}$ and a mean depth of only $55 \mathrm{~m}$. Surface salinities vary from 9 in the southern part to below 1 in the innermost parts (Voipio 1981). Annually, sea ice covers about $40 \%$ of the Baltic Sea (Kaartokallio et al. 2007). Even though the seasonal ice of the Baltic Sea has many similarities with the seasonal ice in the polar areas, fresher water results in sea ice with lower bulk salinities and smaller brine channels, despite the comparably high temperatures (Meiners et al. 2002). Low brine volumes reduce the rate of seawater exchange across the icewater interface that affects rates of nutrient replenishment, convective heat transport, and desalination processes (Lytle and Ackley 1996). Due to milder climate in the Baltic Sea region, snow and freeze-melt cycles occur throughout winter, leading to a greater contribution (up to $35 \%$ ) of sea ice mass in the form of metamorphic snow (Granskog et al. 2006). The high dissolved organic matter (DOM) content in Baltic Sea water and ice leads to different chemical characteristics and causes increased absorption of solar radiation at shorter wavelengths than are utilized for photosynthesis (Granskog et al. 2006). During early winter most of the Baltic Sea is ice free and below the Arctic Circle, where daylight is available for photosynthesis throughout the year in contrast to the polar night in polar regions. As a result, the microbial community differs considerably from polar sea ice environments.

\subsection{Advances in Microbial Ecology}

Advances in marine microbial ecology are driven by methodological advances in understanding both, the environment, as well as the biological taxa that inhabit the environment. Microbial methodology and associated observations advanced marginally from the late 1800s during Nansen's First Fram Expedition to the 1960s and 1970s, where light microscopy and cultivation-based studies of microbes shaped science's understanding of microbial ecology (e.g., Hobbie et al. 1977; reviewed by Baross and Morita 1978). With advancing resolution in microscopy, it was possible to get a better understanding of microbial diversity and abundances that has now ushered in the -omics era. These microbial methodologies have evolved in parallel with in situ technologies. Early approaches measured primary production in slices of an ice core incubated in surrounding ice (Mock and Gradinger 1999). Since these early studies, technological advancements have allowed for in situ measurements of primary production; oxygen microsensors have been used successfully in artificial sea ice experiments to measure in situ ecosystem production (Mock et al. 2002). However, the standard method is to still work on melted sea ice, which may be an underestimation of primary production (Søgaard et al. 
2010). Stable- and radioisotope incubations allowed estimates of microbial activities and associated organic matter utilization. The future of methods for studying biogeochemistry in sea ice may be in situ technologies (reviewed by Miller et al. 2015). Methods for water sampling and biogeochemical studies have been similar to traditional work in other pelagic systems.

The application of molecular fingerprinting methods (e.g., denaturing gradient gel electrophoresis, restriction fragment length polymorphism), clone library sequencing, and in recent years, metagenomics have generated a detailed understanding of microbial phylogeny, taxonomy, and more recently, function and ecology in the seasonal ice zone. Amplicon-based sequencing of the taxonomically informative small ribosomal subunit became a standard genetic barcode, which allowed the identification of microbial taxa down to the level of ecotypes. Advancing sequencing technologies are generating more sequence reads at a lower cost, affording high spatial and temporal resolution of microbial (primarily bacterial) communities and subsequent investigation of their connectivity, seasonal successions, and biogeography (e.g., Brown and Bowman 2001; Brinkmeyer et al. 2003; Collins et al. 2010; Hatam et al. 2016; Yergeau et al. 2017; Rapp et al. 2018). Novel sequencing tools, such as the Nanopore MinION have the potential to be used for in-field sequencing, and have been used in remote polar regions (e.g., Johnson et al. 2017), but not yet in sea ice. Novel sequencing technologies are evolving in parallel with bioinformatic tools that can identify small, yet significant community differences. When used together, these novel sequencing technologies and bioinformatic tools are yielding novel ecological insights that are, in turn, shifting sciences' understanding of microbial community complexity. Consequently, there is an emerging trend away from the traditional $97 \%$ to $98 \%$ similarity cutoff that defines microbial taxa toward network- and nucleotide entropy-based clustering methods (e.g., Rapp et al. 2018).

Recent studies are focusing more on full genome, metagenomic shotgun sequencing approaches. Approaches, which simultaneously generate taxonomic and functional gene information. So far, only several studies have applied metagenomic shotgun sequencing to sea ice samples (e.g., Bowman et al. 2014; Yergeau et al. 2017), but the potential to elucidate complex polar microbial ecology questions is generally unrealized. Metagenomic sequencing efforts have demonstrated bacterial-mediated chemical cycling in frost flowers (Bowman et al. 2014) and the importance of select photoreceptors in Antarctic and Arctic sea ice (Koh et al. 2010; Vader et al. 2018). With increasing throughput of sequence generation and decreasing costs, deep sequencing (i.e., sequencing the same locus multiple times) of the environment should allow comparative studies of full metagenomes to describe the metabolic potential (including uncultured strains) and strain level microbial diversity (e.g., Delmont et al. 2017) in sea ice ecosystems.

Other-omics studies that target byproducts of protein synthesis and secondary metabolism are rare in sea ice. While metagenomics can demonstrate the genetic potential of microbes, RNA-based studies, such as metatranscriptomics, can show whether the genes are expressed. For example, Koh et al. (2010) and Vader et al. (2018) showed that the genes for proteorhodopsin are actively transcribed in Antarctic and Arctic sea ice, indicating an active phototrophic bacterial community. Interdisciplinary research with biochemists identified the functions of translated proteins and ascribed a functional purpose for gene products used in survival and metabolism in sea ice (reviewed by Feller and Gerday 2003; Feng et al. 2014). Metaproteomics is not only possible for cultured bacteria, but can be used for understanding the biochemical functions of the in situ community (Junge et al. 2019). Ultimately, combined -omics studies are important for a thorough understanding of microbial ecology and biogeochemistry (Junge et al. 2019). In cultures, the potential to combine proteomics and genomics has already been shown to help understanding key genes for a life in subzero temperatures (Feng et al. 2014). To date, metaproteomics and metabolomics studies of the whole community have yet to be applied to studies of sea ice.

Ribosomal gene sequencing data have been used to develop fluorescently labeled nucleotide probes that target taxonomically informative genetic loci, namely, fluorescence in situ hybridization (FISH) (Pernthaler et al. 2002). The application of FISH has informed analyses of spatial interactions and abundances of specific taxa, without the known biases associated with DNA sequencing (De Corte et al. 2013), nonspecific fluorescent stains (e.g., 4',6-diamidino-2phenylindole), or cultivation (e.g., Brinkmeyer et al. 2003; Baer et al. 2015). Combined with isotope probing methods, catalyzed reporter deposition-FISH (CARD-FISH) has been used to identify microbial taxa responsible for the uptake of specific organic compounds (e.g., Alonso-Sáez et al. 2008; Nikrad et al. 2012). Consequently, CARD-FISH is a robust method that should be used to supplement DNA sequencing analysis. Only a few of the metabolic capacities mentioned in this chapter have been measured and a common limitation is still the separation of biogeochemical rate measurements and investigations of the genetic potential of communities, or organisms. Studies coupling the function, activity, and diversity of bacteria are lacking in sea ice systems, but their potential has been shown in other marine systems. RNA stable isotope probing is one recent method, which could be used to overcome these limitations. For example, Fortunato and Huber (2016) coupled stable isotope probing with metatranscriptomics to identify taxa and pathways involved in chemolithotrophic processes at hydrothermal vents. Methods for visualization of radioisotope (Microautoradiography, 
(Nierychlo et al. 2016) or stable isotope (Nanoscale secondary ion mass spectrometry, Gao et al. 2016) enrichments in single cells coupled to CARD-FISH could be another method to quantify biogeochemical fluxes of certain taxonomic groups.

One of the major applications of novel ecological data is the incorporation into ecosystem models. Despite the increasing computational power, the representation of microbial interactions in ecosystem models is still rudimentary. For example, bacterial activities are often hidden in functions for organic matter remineralization and respiration (e.g., Tedesco et al. 2010; Wassmann et al. 2010; Vancoppenolle and Tedesco 2017). A recent ecosystem model in the Baltic Sea started realizing for the first time the importance of bacteria beyond nutrient remineralization. Specifically, aerobic and anaerobic bacterial taxa were separately considered, both as crucial for remineralization processes and for generating anaerobic conditions linked to algal production (Tedesco et al. 2017). Linking metabolic pathway models, bacterial functions (such as denitrification and nitrogen fixation), and viral lysis may further improve the accuracy of models with increasing data availability and computational power. In most ecosystem models and discussions, the role of sea ice bacteria and archaea is seen in the heterotrophic aerobic remineralization of DOM (e.g., Tedesco et al. 2010; Wassmann et al. 2010; Vancoppenolle and Tedesco 2017).

\subsection{Sea Ice-Associated Microorganisms}

The base of polar food webs is comprised of microbial organisms allied to multiple clades of life. Polar organisms are well adapted to the seasonality of light, nutrient/food availability, and cold temperatures. Additional challenges arise for ice-associated biota, with extreme cold temperatures, highly variable salinities and only temporary existence of their habitat (Meier et al. 2014). The balance between producers and consumers seasonally shifts with light availability which drives taxa-specific abundances. Diatoms and other microalgae (haptophytes, prasinophytes, dinoflagellates) are some of the most common eukaryotic producers that support a diverse heterotrophic community of prokaryotes, fungi, and fungal-like organisms, ciliates, and larger multicellular organisms. These organisms are all presumably susceptible to viral infection, which can rapidly shunt organic material into the available dissolved organic material pool. Together, these organisms cycle carbon and exchange genes that maintain ecosystem function and support the feeding needs of higher trophic levels.

\subsubsection{Microalgae}

The microalgae community in polar sea ice is dominated by diatoms that comprise the most biomass and greatest species richness, including up to 170 species predominated by Nitzschia sp., Thalassiosira sp., Fragilariopsis sp., and Navicula sp. (Arrigo 2010). Pennate diatoms dominate the spring ice algal bloom in Arctic FYI, as well as in Antarctic sea ice due to the nutrient-rich Southern Ocean (Arrigo et al. 2014). Sea ice associated phytoplankton blooms are often dominated by aggregates of Phaeocystis sp., capable of producing large biomasses and drawing down large amounts of nutrients (Assmy et al. 2017). Other algae groups in the picoand nanoplankton-size fraction contribute substantially to the pelagic and sympagic winter community. Micromonas sp., Cyanobacteria, and Ostreococcus sp. have been found to be abundant phytoplankton species in the polar night (Joli et al. 2017; Amargant Arumí 2018) but only constitute a small fraction of the biomass during spring and summer (Riedel et al. 2008; Niemi et al. 2011; Vader et al. 2018) and therefore have not been studied in more detail until recently. Still, reliable identification and quantification of pico- and nanosized eukaryotes are lacking (Piwosz et al. 2013) or are purely based on sequencing (Vader et al. 2018).

As a consequence of the lower water salinity and corresponding small-sized brine ice channels, the Baltic Sea ice is dominated by smaller protists (Kaartokallio et al. 2007). In early spring, centric diatoms dominate under-ice biomass. These centric diatoms are supplemented by large contributions of Melosira arctica and the cyanobacterium Aphanizomenon sp. that can predominate abundances in the brine channels (Majaneva et al. 2017). In contrast to Arctic and Antarctic sea ice communities, dinoflagellates and green algae contribute to a large fraction of the biomass in Baltic Sea ice and open water (Kaartokallio et al. 2007; Piiparinen et al. 2010). Furthermore, the surface-layer algal biomass can significantly contribute to the overall sea ice algal biomass (Meiners et al. 2002; Piiparinen et al. 2010). So far, the knowledge of species composition and distribution is limited, and there is only little known on the overwintering of cyanobacteria, which are typical for the Baltic Sea (Laamanen 1996).

\subsubsection{Bacteria}

The most common orders found in sea ice are Alteromonadales (Gammaproteobacteria) and Flavobacteriales (Bacteroidetes) with the most common genera Pseudoalteromonas, Colwellia, Shewanella, Flavobacterium, and Polaribacter (Bowman et al. 2012, 2014; Boetius et al. 2015; Yergeau et al. 2017). Rarer phyla are the Alphaproteobacteria, Betaproteobacteria, 
Actinobacteria, and Firmicutes (Bowman et al. 2012, 2014; Boetius et al. 2015; Yergeau et al. 2017). Archaea are mainly found in autumn and winter; they consist primarily of the genus Nitrosopumilus, known for its nitrification capability (Brinkmeyer et al. 2003; Collins et al. 2010). However, most studies are biased toward sampling in summer and spring, but a few studies in winter indicate differences in communities (Collins et al. 2010). On the operational taxonomic unit (OTU) level (97\% cutoff), there seem to be no endemic species for sea ice in certain ice zones so far (reviewed by Deming and Collins 2017), but further studies focusing on strain variability may find differences. It has been shown that the bacterial OTUs are more variable in seasonal sea ice and more related to temperate communities compared to MYI (Hatam et al. 2016). Several bacteria found are known to be psychrophilic (e.g., Feng et al. 2014), and a large fraction could be cultured (up to 60\%, Junge et al. 2002). The bacterial and archaeal communities in the water column of sea ice systems are significantly different with Nitrosopumilus sp., Pelagibacter sp., Flavobacteriales sp., and Oceanosprillaceae sp. as dominating taxa (e.g., Bowman et al. 2012, 2014; Yergeau et al. 2017), indicating a strong selection of potentially endemic sea ice bacteria.

\subsubsection{Fungi}

Fungi are eukaryotic, spore-bearing, heterotrophic organisms that secrete extracellular enzymes used for interfacing symbiosis and facilitating osmotrophy. Within this ecological definition, fungi are a polyphyletic functional group that include the Labyrinthulomycota, Mesomycetozoea, Oomycota, select Amoebozoa, the True Fungi, and several additional clades. True Fungi are distinct from ecological fungi (fungal-like organisms) by possessing cell walls made of chitin and forming a molecular monophyletic clade among the opisthokonts. The True Fungi include many prominent mycelial-producing members, such as the Ascomycota, Basidiomycota, and Mucoromycota, as well as reduced zoosporic varieties, such as the Blastocladiomycota, Chytridiomycota, and Neocallimastigomycota. In this review, fungi are explored within their ecological definition, unless otherwise noted. The often inconspicuous morphology of fungi has challenged the easy identification and subsequent integration of mycological data into ecosystem ecology. As a result, the relevance of fungi remains unrealized in ecosystem modeling efforts globally. Historical culturing-based studies have resulted in the description of hundreds of marine fungal species (Johnson and Sparrow 1961; Kohlmeyer and Kohlmeyer 2013), whose global distribution remains largely unexplored. The more-recent application of molecular methods to studies of marine ecosystem ecology helps to circumvent challenges associated with visual classification and have identified an abundant and dynamic fungal community in subseafloor sediment (Orsi et al. 2013), in association with pelagic marine snow (Bochdansky et al. 2017), in coastal marine habitats (Ueda et al. 2015; Picard 2017) as parasites of phytoplankton (Hanic et al. 2009; Lepelletier et al. 2014; Hassett and Gradinger 2016; Jephcott et al. 2016; Scholz et al. 2017a, b) and metazoans (Polglase 1980; Mclean and Porter 1982; Bower 1987; Shields 1990; Rahimian 1998). Relative to lower latitudes, knowledge of Arctic marine fungi is considerably less developed, in part due to the logistical constraints and inaccessibility of sampling sites. The state of ecological knowledge on Arctic marine True Fungi has largely centered on establishing presence-absence data, supplemented with baselines of diversity and richness, currently estimated at several hundred species (Rämä et al. 2017), with a low success rate of culturing (Bubnova and Nikitin 2017). DNA sequence-based analysis identified overlapping True Fungi taxa from the Bering Sea region and Svalbard, demonstrating a broad distribution of fungal taxa across the Arctic Ocean (Hassett et al. 2017) that are selectively predominated by the Chytridiomycota (Terrado et al. 2011; Hassett and Gradinger 2016) and comprise a novel, uncharacterized branch of life (Comeau et al. 2016; Hassett et al. 2017). The diversity and distribution of Arctic marine fungal-like organisms is currently unknown and unreported in assessments of unicellular eukaryotic biodiversity (Poulin et al. 2011).

\subsubsection{Viruses}

Historically, the study of viral diversity was limited by the co-cultivation of the virus and its host (Borriss et al. 2003; Wells and Deming 2006b). Sea ice viruses are cold-adapted (Luhtanen et al. 2018) and may be less host-specific than in more temperate regions (Wells and Deming 2006b). Cultivated viruses only include Siphoviridae and Myoviridae as sea ice-specific taxa (Borriss et al. 2003; Wells and Deming 2006a; Sencilo et al. 2015). With increasing -omic efforts, more viruses could be found indicating a higher diversity than previously thought, and taxa such as Podoviridae, Nodaviridae (RNA), Iridoviridae (DNA), and Caudovirales have been detected (Allen et al. 2017).

\subsection{General Ecology of Sea Ice-Associated Microbes}

\subsubsection{Autotrophy}

\subsubsection{Photoautotrophy}

The activity of the microbial food web follows the fixation of carbon and its subsequent turnover into the DOM pool 
(Arrigo and Thomas 2004). While sea ice algal annual primary production rates are generally low compared to the phytoplankton fraction, they are often the main source of fixed carbon for higher trophic levels in ice-covered seas. During winter, ice algae are of special importance, when other sources of food are lacking (Lizotte 2003). Chlorophyll $a(\mathrm{Chl} a)$ concentrations in sea ice vary by region, ice type and season and covers a range somewhat typical for oceanic values up to the highest concentrations found in aquatic environments (Arrigo 2010). In the Arctic, the balance between annual phytoplankton to ice algal primary production differs regionally. In the northern Barents Sea, ice algae account for about 20\% of total primary production (Hegseth 1998), whereas in more heavily ice-covered areas like the Central Arctic Ocean, ice algae can contribute more than 50\% to the total primary production (Gosselin et al. 1997). Chl $a$ concentrations vary between $22 \mathrm{mg} \mathrm{m}^{-2}$ in Allen Bay, Nunavut, during spring (Campbell et al. 2014) and $0.3-8 \mathrm{mg} \mathrm{m}^{-2}$ in the Central Arctic in summer (Fernández-Méndez et al. 2015). In ice-covered waters of the Antarctic, sea ice algae account for up to $25 \%$ of total annual primary production (Arrigo and Thomas 2004). Chl $a$ concentrations vary from 1 to $50 \mathrm{mg} \mathrm{m}^{-2}$ in the Weddel Sea region (Ackley et al. 1979), whereas sea ice attached to the coast of Antarctica (fast ice) accumulates biomass of up to $2120 \mathrm{mg} \mathrm{m}^{-2}$ (Arrigo and Sullivan 1992). On average, under sufficient light intensities for photosynthesis, $\mathrm{Chl} a$ concentrations exceed $200 \mathrm{mg} \mathrm{m}^{-2}$ during spring and summer (Palmisano and Sullivan 1983; Trenerry et al. 2002). In contrast, productivity by sea ice algae in the Baltic Sea is much lower, contributing about $10 \%$ to the primary production during the ice-covered season (Haecky et al. 1999). Average Chl $a$ values range between 0.2 and $5.5 \mathrm{mg} \mathrm{m}^{-2}$ (Haecky et al. 1999; Kaartokallio 2001, 2004).

Based on sequencing results and detection of photopigments, sea ice and sea ice-associated bacteria have also been speculated to be capable of photoautotrophic carbon fixation (Petri and Imhoff 2001; Koh et al. 2011, 2012; Boetius et al. 2015). Despite their high abundance in other cold environments, such as glaciers (Vonnahme et al. 2016), phototrophic cyanobacteria and anoxygenic phototrophs (e.g., purple sulfur bacteria, Chloroflexi) are not as abundant as eukaryotic sea ice algae, but are frequently detected in the Arctic (Petri and Imhoff 2001; Boetius et al. 2015; Yergeau et al. 2017) and Antarctic (Koh et al. 2011, 2012). Their pigments (phycobiliproteins and bacteriochlorophyll), as well as their genes (e.g., 16S rRNA genes), have been found (Cottrell and Kirchman 2009; Koh et al. 2012; Boetius et al. 2015). However, a proof of their phototrophic activity in sea ice is, yet, lacking. Cyanobacteria are more abundant in the snow layer of sea ice suggesting aeolian origin in the Antarctic (Koh et al. 2012). It appears that cyanobacteria are more abundant in fresher systems, such as melt ponds and the
Baltic Sea (Petri and Imhoff 2001; Rintala et al. 2014) and that they become more abundant in winter (Cottrell and Kirchman 2009). In the water column, anoxygenic phototrophs may contribute to up to around $15 \%$ of the bacterial communities in the Arctic, which is 1000 times more than cyanobacteria such as Synechococcus sp. and may indicate a high importance of this pathway in addition to photosynthesis by sea ice algae (Cottrell and Kirchman 2009). In contrast to cyanobacteria, anoxygenic phototrophs appear to be more abundant in summer (Cottrell and Kirchman 2009). Proteorhodopsin, a pigment for using light energy to create a proton motive force, which can be used for energy production, or nutrient transport, is commonly found in seasonal sea ice in the Arctic and Antarctic and can be seen as another way of phototrophic carbon fixation by Alphaproteobacteria, Gammaproteobacteria, and Flavobacterium (Koh et al. 2010, 2012; Yergeau et al. 2017). A combination of these alternative photosynthetic pathways using different wavelengths efficiently may be an important component of the primary production in the seasonal ice zones, but their phototrophic activity has not been quantified in sea ice, yet.

\subsubsection{Chemoautotrophy}

In the water column, chemoautotrophy (inorganic carbon uptake, using chemical energy), appears to be an important autotrophic carbon acquisition process. During nitrification, ammonium is used as energy source, which delivers energy during reduction to nitrite and nitrate for inorganic carbon fixation. The ammonium originates commonly from primary production by sea ice algae and phytoplankton. The nitrate produced via nitrification can be used as recycled inorganic nitrogen for primary production. Archaea constitute a large fraction of potential nitrifiers in the water column, with significantly higher abundances than in sea ice (Yergeau et al. 2017). Nitrifying bacteria appear to be important in coastal areas of the Arctic seasonal ice zone, potentially due to a high supply of ammonium from the bottom water (Damashek et al. 2017). Nitrifying taxa have also been found in deeper stations, but nitrifying archaea are more abundant (e.g., Yergeau et al. 2017). Other autotrophic pathways have not been described yet and are rather unlikely due to the lack of sources for reduced ions in sea ice.

Aerobic bacterial production may become high enough to leave anoxic pockets in the sea ice, where anaerobic processes become energetically favorable. Denitrification and anaerobic ammonia oxidation (Anammox) rates comparable to sediments have been measured in sea ice, reducing the overall nitrogen availability for primary production (Rysgaard and Glud 2004; Rysgaard et al. 2008). New production of nitrogen is possible via upwelling from nutrientrich bottom waters, bacterial recycling of organic matter, or $\mathrm{N}_{2}$ fixation. So far, the nifH gene for nitrogen fixation has been detected in Arctic seasonal sea ice connected to a 
diverse group of cyanobacteria (Diez et al. 2012). The potential for nitrogen fixation has also been found in the central Arctic Ocean, but the genes are mainly related to heterotrophic bacteria indicating different communities for $\mathrm{N}_{2}$ fixation in the Arctic (Fernández-Méndez et al. 2016). However, the importance of nitrogen fixation in sea ice remains unclear until nitrogen fixation has been measured directly or the gene expression has been assessed via omics approaches. Nitrogen fixation measurements from open water in the seasonal ice zone suggest that $27.1 \%$ of the nitrogen lost via denitrification can be resupplied via nitrogen fixation (Sipler et al. 2017).

\subsubsection{Others}

Other biogeochemical cycles have been discovered in metagenomic and metatranscriptomic datasets (reviewed by Bowman 2015), indicating the potential for mercury cycling and dimethyl sulfide (DMS) production (Bowman et al. 2014), hydrocarbon degradation (Gerdes et al. 2005), and vitamin B12 synthesis (Taylor and Sullivan 2008) in and under sea ice, all processes which can effect primary production in sea ice-covered seas.

\subsubsection{Mixotrophy}

Mixotrophy in algae is the combination of a heterotrophic (phagotrophic and/or osmotrophic) and phototrophic nutritional mode within a single cell (Sanders 1991). The awareness of the importance of mixotrophic behavior in aquatic systems has increased tremendously (Hansen 2011) and has been reported to be widespread among flagellate algal groups such as dinoflagellates, prymnesiophytes, and cryptophytes in the marine system (Ballen-Segura et al. 2017). Many bloom-forming algal species have been recognized to be mixotrophs causing an increased interest in this field. The potential benefits of particle ingestion include the acquisition of organic carbon, energy, major nutrients, vitamins, and trace metals (Caron et al. 1993). Mixotrophy is particularly beneficial when there is a limitation in inorganic nutrients (Unrein et al. 2014) or light availability (Hansen 2011). Under oligotrophic conditions, flagellated algae can account for up to $80 \%$ of total bacterial grazing (Unrein et al. 2007; Sanders and Gast 2012). Predation by flagellated algae is among the primary mortality factors of prokaryotes in planktonic communities, constituting an important selective pressure (Ballen-Segura et al. 2017).

The Arctic nanoplankton species Micromonas pusilla is abundant in polar waters throughout the year and was identified as being independent of the availability of light based on a mixotrophic life style (Unrein et al. 2007; Sanders and Gast 2012). Under thick ice cover in the Canadian Arctic, Micromonas sp. contributed up to $93 \%$ of autotrophic cell abundance (Sherr et al. 1997). Micromonas pusilla ingests higher rates of fluorescently labeled bacteria at oligotrophic conditions, but only if exposed to light. This suggests that the ingestion supplemented nitrogen and/or phosphorus supply to allow for balanced growth when photosynthesis rate is high (McKie-Krisberg and Sanders 2014). In the dark, the tested strain would take up less fluorescently labeled bacteria, which points to an osmotrophic uptake of carbon and energy.

Although the potential importance of mixotrophy within the sea ice community has been recognized, comparably few studies have focused on this environment. Facultative heterotrophy and energy storage have been suggested to be the main processes enabling winter survival in sea ice (Syvertsen 1991; Zhang et al. 2003). Piwosz et al. (2013) found bacterial cells in the food vacuoles of picoeukaryotes from various trophic groups in FYI of the Arctic. Phagotrophic ingestion was investigated in mixotrophic nanoflagellates (MNF) of Antarctic sea ice during spring where they comprised 5-10\% of the autotrophic nanoflagellates (Moorthi et al. 2009). Mixotrophy has been proposed to be an important mode of winter survival in sea ice algae. However, Horner and Alexander (1972) only found low uptake rates of organic substances by sea ice diatoms. Osmotrophy is widespread among pennate and centric diatoms from Antarctic and Arctic marine environments. The uptake rate of organic material is dependent on solar radiation and shows great interspecific variability (Ruiz-González et al. 2012). Algae are able to take up a variety of organic substrates such as pyruvate, acetate, lactate, ethanol, saturated fatty acids, glycerol, urea, and amino acids (Parker et al. 1961; Lewin and Hellebust 1976; Amblard 1991; Bronk et al. 2007). RuizGonzáles et al. (2012) concluded that osmotrophy together with phagotrophy suggest that algae may play a more diverse role in aquatic biogeochemical cycles than only supplying heterotrophs with photosynthetically fixed organic matter.

\subsubsection{Cryptic Carbon Cycling and Underrepresented Microbes}

Both ecological and phylogenetic fungi are prominent parasites of cyanobacteria, macro-algae, and animals that also biogeochemically cycle nutrients and degrade recalcitrant molecules. Fungal-like organisms in the Oomycota have been reported as parasites on algae in the Canadian Arctic (Küpper et al. 2016) and have been observed in the Norwegian Sea and Svalbard region (Fig. 14.1). The detection of fungi on Arctic marine bird feathers (Singh et al. 2016) and in association with driftwood (Rämä et al. 2014) suggests additional ecological niches occupied by the fungi that currently remain unexplored. Arctic members of the Labyrinthulomycota can exceed $10^{5}$ cells $\mathrm{L}^{-1}$ (Naganuma 
(a)

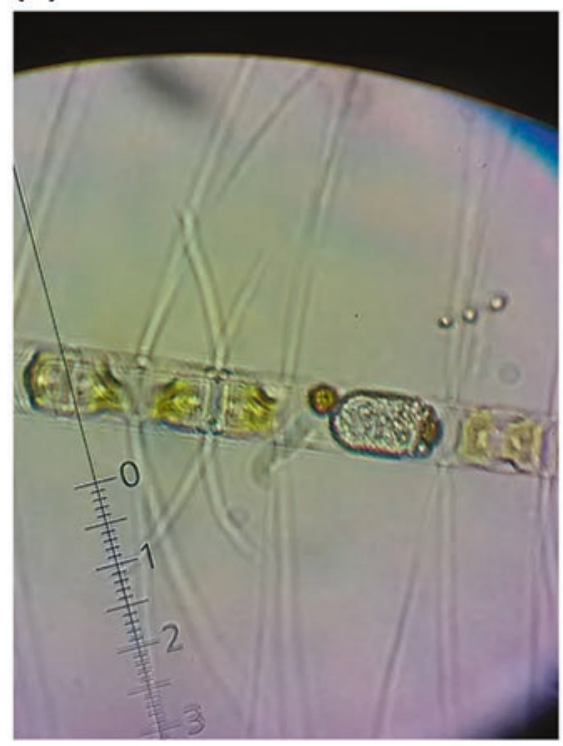

(b)

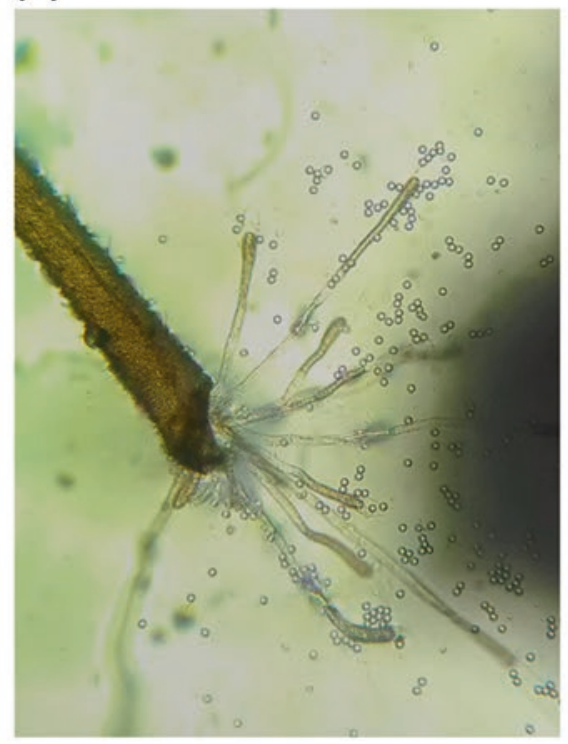

(c)

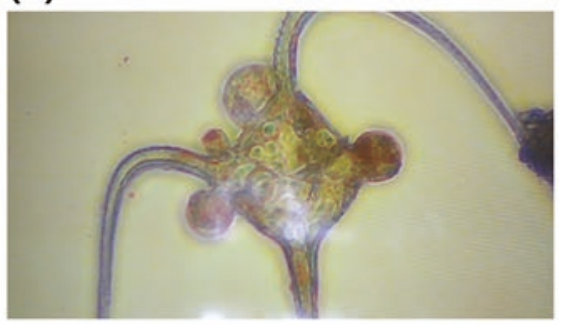

(d)

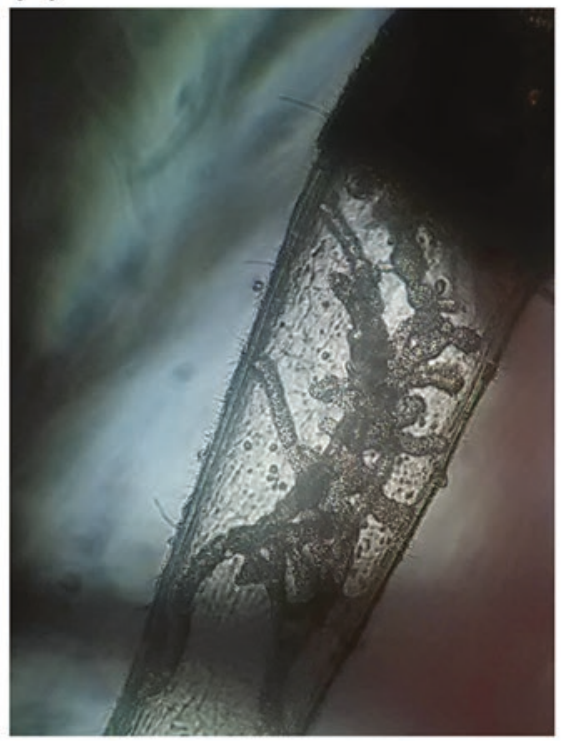

Fig. 14.1 Unidentified fungi and fungal-like pathogens. (a) A probable oomycete pathogen of Chaetoceros sp. captured in southern Norway (Drøbak). (b) A probable oomycete pathogen (Saprolegnia sp.) fruiting at the tip of benthic red macro-algae (image from samples collected in
Drøbak by the authors). (c) Unknown pathogen parasitizing the dinoflagellate Tripos sp. in a Troms $\emptyset$ fjord (photo provided by Richard Ingebrigtsen, UiT). (d) Unknown pathogen with extensive branching inside a benthic red algae. (Image from Drøbak) et al. 2006) and are capable of degrading pine pollen (Hassett and Gradinger 2018), suggesting that these organisms might be seasonally important in degradative processes. Members of the Mesomycetozoea (namely, the genus Ichthyophonus) primarily exist as parasites of Arctic fish (Klimpel et al. 2006) but whose abundance, distribution, and relevance to other ecosystem processes remain unknown.

Ecologically, the Arctic marine Chytridiomycota are seasonally abundant parasites that can infect approximately $1 \%$ of all diatoms in the near-shore sea ice environment (Hassett and Gradinger 2016) and $25 \%$ of a single diatom species (Hassett et al. 2017). Specifically, the Chytridiomycota parasitize light-stressed diatoms within sea ice brine channels (Horner and Schrader 1982; Hassett and Gradinger 2016). True Fungi have been reported in sea ice as far north as the North Pole (Bachy et al. 2011) and across the Western Arctic (Hassett et al. 2017). Beyond these observations, there is little information detailing the sea ice ecology of Fungi and fungal-like organisms. Seawater advection into sea ice and entrainment processes of particulates (Eicken et al. 2005;
Gradinger et al. 2009) suggest that many fungi and fungallike organisms observed in sediments and seawater are likely present in sea ice. However, little to no known specific empirical evidence exists to suggest this phenomenon.

Viruses play an important role in nutrient recycling via the viral shunt. Especially in winter and autumn, viral lysis is known to be the most important mortality factor for bacteria (Krembs et al. 2002b). Besides, viruses may have important roles for horizontal gene transfer. In an extensive virome study by Allen et al. (2017), a diverse virus community was found, including viruses with photosystem genes. Data mining of published metagenomes and metatranscriptomes revealed similar patterns of evolutionary important genes (e.g., photosystem) in viruses. The sea ice metagenome from Cottrell and Kirchman (2012), for example, showed cyanophages, synechococcus phages, and prochlorococcus phages with photosystem genes in their genome. The high bacterial density in sea ice, the close spatial connection, and low host specificity may allow a rather quick evolution via viral gene transfer compared to other systems. This may help to develop 
hypotheses on the evolution of life and life on other planets, such as Europa. With further studies of transposons in metagenome assembled genomes, these hypotheses can be developed and tested further.

\subsection{Seasonal Cycle in Ice-Covered Seas}

Sea ice-covered systems are characterized by highly seasonal variabilities of temperature and light. In sea ice, brine channels spatially constrain biota and increase interactions between consumers (bacteria and fungi) and primary producers. Therefore, the sea ice habitat is more comparable to biofilms and processes taking place within biofilms (Krembs et al. 2000). Ice algae and bacteria release extracellular polymeric substances (EPS) that protect cells from high salinities and low temperatures, foster the adhesion to surfaces, and alter the microstructure and corresponding desalination processes of sea ice (Krembs et al. 2011). Thus, sympagic microalgae and bacteria can cause physical changes to their immediate environment, improving sea ice habitability (Krembs et al. 2002a, 2011). Concentration and chemical composition of EPS significantly differed in response to gradients in temperature and salinity in Antarctic sea ice and simulated sea ice formation experiments with cultures of the bi-polar diatom Fragilariopsis cylindrus (Aslam et al. 2018). Under combined conditions of low temperature and high salinity, the relative contribution of EPS to total carbohydrates and their monosaccharide composition changed significantly, both in the field and lab. Increased concentrations of uronic acids and mannose at low temperatures increase the stiffness of EPS gels (Aslam et al. 2012), needed to produce protective cell coatings as observed in natural sea ice brines.

The initial colonization stage during sea ice formation is followed by a low-productive, heterotrophic winter stage, dominated by pelagic organisms (Fig. 14.2) (Grossmann and Gleitz 1993; Joli et al. 2017; Amargant Arumí 2018). Biomass accumulation follows the seasonal increase in solar radiation during winter-spring transition. The sea ice algal bloom is terminated either by nutrient depletion or sea ice melt in late spring/early summer. At the ice edge phytoplankton blooms of Phaeocystis sp. may contribute to high primary production (Assmy et al. 2017). The post-bloom stage is dominated again by heterotrophic processes in the sea ice and water column (Haecky et al. 1999; Kaartokallio 2004).

\subsubsection{Autumn}

In autumn, sea ice starts forming as frazil ice, which can form at the surface or in deeper water layers (Petrich and Eicken 2010). During ice formation, larger particles, such as eukaryotes or sediment particles, can be transported to the water surface and incorporated into the ice. Ice formation begins in autumn when there are still substantial microbial populations left over in surface waters from the preceding spring bloom (Arrigo and Thomas 2004). As the frazil crystals rise to the surface, particles such as microalgae, heterotrophic protists, and bacteria are scavenged (Garrison et al. 1989). During wave movement, the frazil ice may further act as a sieve, concentrating biomass from the water column (Reimnitz et al. 1993; Weissenberger and Grossmann 1998). This process is thought to select for sticky bacteria, diatoms and organisms attached to larger organisms or particles (Grossmann and Dieckmann 1994; Weissenberger and Grossmann 1998). Another concentration process is the brine exclusion during the ice formation, concentrating nutrients, salts, and organisms in small and densely packed brine channels (reviewed by Deming and Collins 2017). The brine channels are very rich in nutrients and organic matter but may limit bacterial and algal activities at low temperatures and high salinities, which may fluctuate greatly. Thus, the organisms that are concentrated into the ice are further selected by their capability to survive or grow in the extreme physical conditions (Grossmann and Dieckmann 1994). Survival may be enhanced by EPS production or cryoprotectants and changes in biochemical structures to withstand osmotic shock and freezing (Krembs et al. 2011). Studies in the autumn are rare, but the overall bacterial production is low compared to the rest of the year and exceeds that by microalgae (Grossmann and Dieckmann 1994). Grazing seems to be a minor impact, while viruses and phages are enriched 10-100 times (e.g., Gowing et al. 2002; Collins and Deming 2011). Knowledge on bacterial and algal diversity and functions are rare, but the community structures seem to differ from the other seasons and are more similar to the seawater below the newly forming sea ice (Collins et al. 2010). Archaea and oligotrophic bacteria (e.g., OM182) become more dominant, while Alteromonadales become less abundant (Collins et al. 2010). Throughout the winter, large centric diatoms are gradually reduced, shifting to a dominance of small pennate species such as Fragilariopsis sp. (Lizotte 2003). A water column bloom may start due to the nutrient upwelling after autumn storms which are increasingly abundant with the effects of climate change and retreating sea ice (Ardyna et al. 2014).

\subsubsection{Winter}

In winter, the temperature in sea ice drops and the brine volume may decrease giving little space for eukaryotes and high concentrations of DOM for bacteria (reviewed by Deming and Collins 2017). Absence of light, extreme salinities, and cold temperatures challenge the microbial survival and 


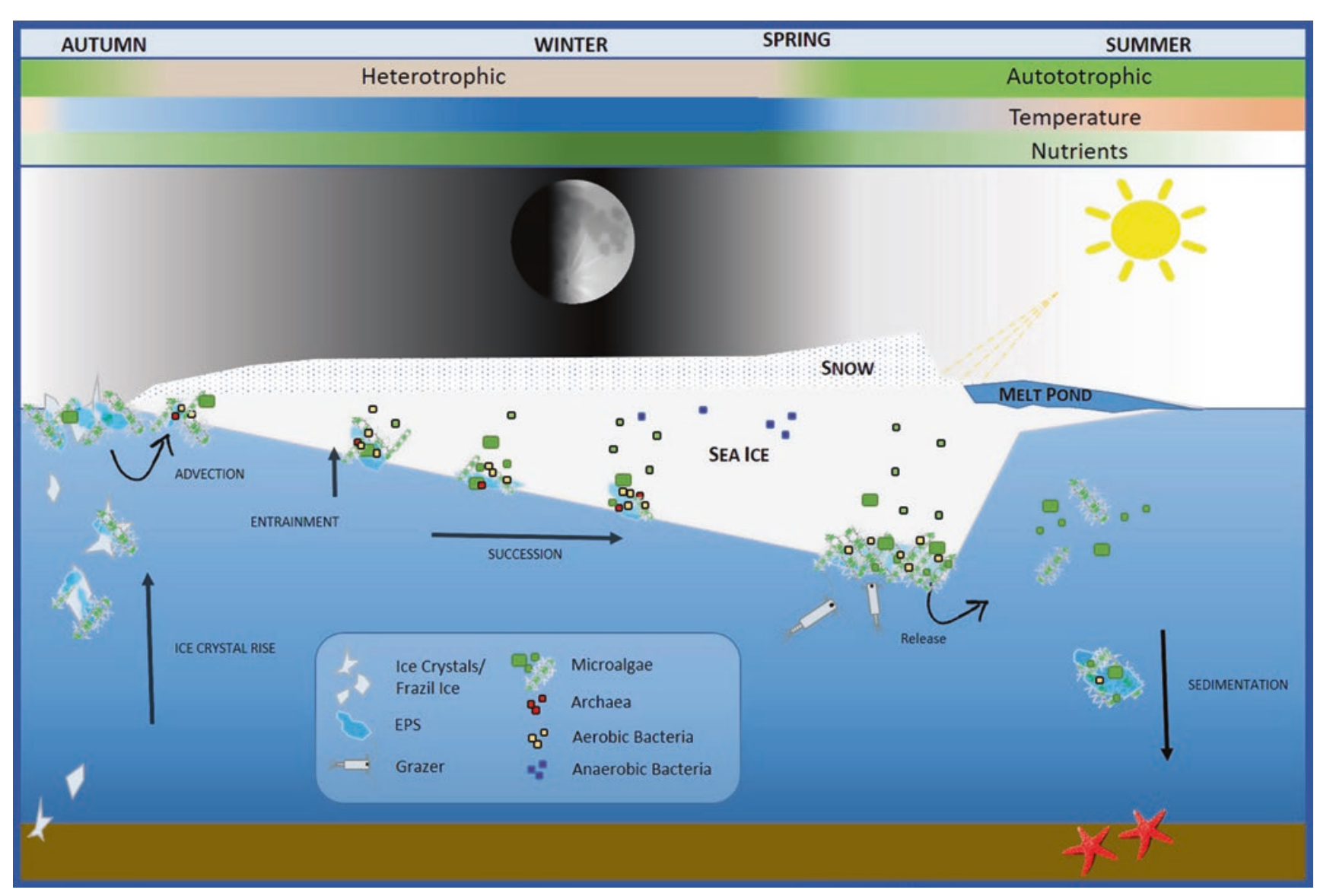

Fig. 14.2 Sea ice and microbial dynamics in the seasonal ice zone. Figure produced based on references in the text

activities. Grazers are mostly absent in winter and bacterial mortality is mainly caused by viral lysis (Krembs et al. 2002a). Overall, bacterial production is low, but certain bacteria are active allowing viruses to produce (Wells and Deming 2006a, b). Up to $86 \%$ of winter sea ice bacteria have been found to be active in FISH counts and 4\% showed respiration during 5-Cyano-2,3-ditolyl tetrazolium chloride staining (Junge et al. 2004). Bacterial activity is crucial for surviving the harsh conditions, ion transporters have to be active and the membranes intact to compensate for large osmotic differences between the brine water and cell interior transportation of ions and compatible solutes (Collins and Deming 2013). EPS has been found in winter sea ice, which can be important as cryoprotectant and which is mostly produced by bacteria due to the low abundances of eukaryotic algae (Krembs et al. 2002b, 2011). As in autumn, heterotrophic bacterial production is higher than primary production, making the system net heterotroph (Kottmeier and Sullivan 1987). Little is known about the community structure, but the community becomes more similar to typical heterotrophic sea ice communities. Archaea appear more abundant in winter and autumn sea ice, compared to spring and summer indicating their potential importance for autotrophic nitrification (Brinkmeyer et al. 2003; Collins et al. 2010). The microalgal winter diversity in the Beaufort Sea is similar to spring with pennate diatoms dominating, and Nitzschia frigida being the most abundant species (Niemi et al. 2011). The dominance of pennate diatoms during the spring algal bloom indicates a competitive advantage, due to their high production rates of EPS and potential for heterotrophy as survival strategies (Niemi et al. 2011). In the water column, picophytoplankton becomes dominant with Micromonas sp., Ostreococcus sp., and cyanobacteria as main phototrophic organisms (Vader et al. 2015; Joli et al. 2017; Amargant Arumí 2018). In the absence of light, mixotrophic pathways may be important for their survival and explain their dominance (Sanders and Gast 2012; Vader et al. 2015). Nitrifier abundances based on bacterial and archaea amoA genes in the Arctic water column may become 30-115 times more abundant in winter indicating that nitrification may be an important autotrophic process (Christman et al. 2011). 


\subsubsection{Spring}

With the returning sun and increasing temperatures in spring, microbial activities generally increase. At the bottom of the ice, sea ice algae may form blooms supporting bacterial production. The under-ice production is generally higher than in autumn and winter but only about $10 \%$ of sea ice algal production (Deming and Collins 2017). In the upper ice layers, bacterial activity is still increasing to levels higher than algal primary production (Gradinger and Zhang 1997). The production can be fueled by degradation of cryoprotectants (e.g., EPS) which are not needed anymore, or by old organic matter (Collins and Deming 2013; Arrigo et al. 2014; Firth et al. 2016). Overall, the system may become net heterotrophic and even anoxic, allowing denitrification and annamox to play a role (Rysgaard et al. 2008; Rysgaard and Glud 2004). In oxygenated zones, bacteria play an important role in recycling nutrients from organic matter into ammonium and eventually into nitrate (e.g., Rysgaard et al. 2008). Viral concentrations increase, but viral lysis is a minor mortality factor of bacterial mortality, while microzooplankton grazing becomes more important (Maranger et al. 1994; Piwosz et al. 2013). The community structure changes toward a community with significantly less archaea and more representatives of the Alteromonadales clade (Collins et al. 2010), indicating a system in favor of faster-growing heterotrophic bacteria. Primary production in the water column is limited by light absorbed through the sea ice.

\subsubsection{Summer}

In summer, the sea ice starts melting from the bottom releasing concentrated organic matter and algal biomass. Large algae aggregate together with their bacterial community may sink to the bottom seeding sediment communities and feeding deep-sea animals (Rapp et al. 2018). In the deep central basins, this process may be a permanent loss, while seeding of new sea ice with the sediment communities is possible down to depth of about $30 \mathrm{~m}$. With a retreating seasonal ice zone toward the central Arctic Ocean, this may become problematic. The communities are dominated by Flavobacteriia and Gammaproteobacteria, but Flavobacteriia are only a minor fraction in sediment associated communities and autumn communities (Collins et al. 2010; Rapp et al. 2018). Archaea are mostly absent (Collins et al. 2010). The water column becomes more heterotrophic with increased bacterial production with decreasing phytoplankton biomass (Kirchman et al. 2009) and a community shift toward heterotrophs and mixotrophs (e.g., Stoecker et al. 2014).

\subsubsection{Climate Change Effects}

Changes in sea ice properties are forecasted to drive climate feedback loops and impact biological processes, such as element cycling (Holding et al. 2015; Tremblay et al. 2015). As sea ice melting starts earlier in the year, habitat loss occurs before solar radiation is sufficient for algal productivity and growth in the high Arctic (Arrigo et al. 2008) and near the Antarctic Peninsula. Sea ice algae are an important highquality energy source for grazers in early spring and can seed the pelagic phytoplankton bloom. A shift or loss of the sea ice bloom is forecasted to change the productivity of the system and negatively affect the reproduction success of highly synchronized grazers like Calanus glacialis (Søreide et al. 2010), krill (Hoshiai et al. 1987), and of calanoid copepods such as Acartia bifilosa (Werner and Auel 2004) in the Arctic, Antarctic, and Baltic, respectively. In addition, the nutrient and light conditions in which sea ice algae thrive induce the synthesis of polyunsaturated fatty acids, a crucial constituent of the diet of grazers, especially during winter (Nichols et al. 1999; Arrigo and Thomas 2004). Increased light intensities reduce the nutritional value of ice-associated (sympagic) microalgae (Leu et al. 2010). Due to warming, the water column may become more stratified (Tremblay et al. 2015), reducing the vertical supply of nutrients to the euphotic zone. On the other hand, a longer ice-free period might counteract stratification through re-mixing of nutrients by wind and storms, but only minor effects on vertical mixing could be observed (Toole et al. 2010; Lincoln et al. 2016). Extended ice-free periods and thinner sea ice in the Arctic increases light availability to pelagic and sympagic microalgae, enhancing annual primary production (Wassmann et al. 2011). The community structure may shift to more pelagic algae species, such as Phaeocystis sp. (Assmy et al. 2017). However, the overall consequences of sea ice retreat on primary production remain under debate (Arrigo et al. 2014; Tremblay et al. 2015).

\subsection{Conclusions}

Knowledge on the distribution and abundance of sea ice protists is crucial to understand and foresee possible changes in microbial communities that potentially have great impacts on food webs of the ice-covered oceans. Even though -omics provide thorough insights into species composition and processes, one should not neglect the importance of assessing their respective abundances. New methods have the potential to shed more light onto the functions of sea ice microorganisms. However, one should not overlook the limitations and restrictions when it comes to sea ice sampling. Melting of sea ice material exposes organisms to changes in physical and chemical conditions, to which microorganisms might 
react instantaneously. Good care needs to be taken to manipulate the community as little as possible. In the future, the development of good practices and standards is crucial to ensure intercomparable observations of ice biota and properties. A strong seasonality in the seasonal ice zone determines the community structures and functions of the sea ice ecosystem and the associated water column. With climate change, some of the annual processes change (e.g., timing of ice formation), while others will stay the same (length of the polar night). This will eventually change the communities and functions in sea ice, as we know it now. We believe that a focus on microbes, and a proportional representation of their activity (relative to their biomass contributions) in ecosystem models will help to forecast the biological fate of polar marine ecosystems under forecasted climate change scenarios.

\section{Appendix}

This article is related to the YOUMARES 9 conference session no. 17: "Bridging disciplines in the seasonal ice zone (SIZ)." The original Call for Abstracts and the abstracts of the presentations within this session can be found in the Appendix "Conference Sessions and Abstracts", Chapter "13 Bridging disciplines in the seasonal ice zone (SIZ)", of this book.

\section{References}

Ackley SF, Buck KR, Taguchi S (1979) Standing crop of algae in the sea ice of the Weddell Sea Region. Deep-Sea Res I 26:269-281. https://doi.org/10.1016/0198-0149(79)90024-4

Allen LZ, McCrow JP, Ininbergs K et al (2017) The Baltic Sea virome: diversity and transcriptional activity of DNA and RNA viruses. Msystems 2:e00125-e00116. https://doi.org/10.1128/ mSystems.00125-16

Alonso-Sáez L, Sanchez O, Gasol JM et al (2008) Winter-to-summer changes in the composition and single-cell activity of near-surface Arctic prokaryotes. Environ Microbiol 10:2444-2454. https://doi. org/10.1111/j.1462-2920.2008.01674.x

Amargant Arumí M (2018) Arctic marine microbial ecology during the Svalbard Polar Night. Master thesis, UiT Norges arktiske universitet

Amblard C (1991) Carbon heterotrophic activity of microalgae and cyanobacteria - ecological significance. Ann Biol-Paris 30:6-107

Ardyna M, Babin M, Gosselin M et al (2014) Recent Arctic Ocean sea ice loss triggers novel fall phytoplankton blooms. Geophys Res Lett 41:6207-6212. https://doi.org/10.1002/2014gl061047

Arrigo KR (2010) Marine microalgae in Antarctic sea ice. Integr Comp Biol 50:E5-E5

Arrigo KR, Sullivan CW (1992) The influence of salinity and temperature covariation on the photophysiological characteristics of Antarctic sea ice microalgae. J Phycol 28:746-756. https://doi. org/10.1111/j.0022-3646.1992.00746.x

Arrigo KR, Thomas DN (2004) Large scale importance of sea ice biology in the Southern Ocean. Antarct Sci 16:471-486. https://doi. org/10.1017/S0954102004002263
Arrigo KR, van Dijken G, Pabi S (2008) Impact of a shrinking Arctic ice cover on marine primary production. Geophys Res Lett 35:L19603. https://doi.org/10.1029/2008GL035028

Arrigo KR, Perovich DK, Pickart RS et al (2014) Phytoplankton blooms beneath the sea ice in the Chukchi Sea. Deep-Sea Res II 105:1-16. https://doi.org/10.1016/j.dsr2.2014.03.018

Aslam SN, Strauss J, Thomas DN et al (2018) Identifying metabolic pathways for production of extracellular polymeric substances by the diatom Fragilariopsis cylindrus inhabiting sea ice. ISME J 12:1237-1251. https://doi.org/10.1038/s41396-017-0039-z

Aslam SN, Cresswell-Maynard T, Thomas DN et al (2012) Production and characterization of the intra- and extracellular carbohydrates and polymeric substances (EPS) of three sea-ice diatom species, and evidence for a cryoprotective role for EPS. J Phycol 48:1494-1509. https://doi.org/10.1111/jpy.12004

Assmy P, Fernández-Méndez M, Duarte P et al (2017) Leads in Arctic pack ice enable early phytoplankton blooms below snow-covered sea ice. Sci Rep 7:40850. https://doi.org/10.1038/srep40850

Bachy C, Lopez-Garcia P, Vereshchaka A et al (2011) Diversity and vertical distribution of microbial eukaryotes in the snow, sea ice and seawater near the North Pole at the end of the polar night. Front Microbiol 2:106. https://doi.org/10.3389/fmicb.2011.00106

Baer SE, Connelly TL, Bronk DA (2015) Nitrogen uptake dynamics in landfast sea ice of the Chukchi Sea. Polar Biol 38:781-797. https:// doi.org/10.1007/s00300-014-1639-y

Ballen-Segura M, Felip M, Catalan J (2017) Some mixotrophic flagellate species selectively graze on archaea. Appl Environ Microbiol 83:e02317-e02316. https://doi.org/10.1128/AEM.02317-16

Barber DG, Hop H, Mundy CJ et al (2015) Selected physical, biological and biogeochemical implications of a rapidly changing Arctic Marginal Ice Zone. Prog Oceanogr 139:122-150. https://doi. org/10.1016/j.pocean.2015.09.003

Baross J, Morita R (1978) Microbial life at low temperatures: ecological aspects. In: Kushner DJ (ed) Microbial life in extreme environments. Academic Press, London, pp 9-71

Beitler J (2012) Arctic sea ice extent settles at record seasonal minimum. National Snow and Ice Data Center. http://nsidc.org/ arcticseaicenews/2012/09/arctic-sea-ice-extent-settles-at-recordseasonal-minimum/. Accessed 1 Feb 2016

Berge J, Daase M, Renaud P et al (2015) Unexpected levels of biological activity during the polar night offer new perspectives on a warming Arctic. Curr Biol 25:2555-2561. https://doi.org/10.1016/j. cub.2015.08.024

Bluhm BA, Hop H, Vihtakari M et al (2018) Sea ice meiofauna distribution on local to pan-Arctic scales. Ecol Evol 8:2350-2364. https:// doi.org/10.1002/ece3.3797

Bochdansky AB, Clouse MA, Herndl GJ (2017) Eukaryotic microbes, principally fungi and labyrinthulomycetes, dominate biomass on bathypelagic marine snow. ISME J 11:362-373. https://doi. org/10.1038/ismej.2016.113

Boetius A, Anesio AM, Deming JW et al (2015) Microbial ecology of the cryosphere: sea ice and glacial habitats. Nat Rev Microbiol 13:677-690. https://doi.org/10.1038/nrmicro3522

Borriss M, Helmke E, Hanschke R et al (2003) Isolation and characterization of marine psychrophilic phage-host systems from Arctic sea ice. Extremophiles 7:377-384. https://doi.org/10.1007/ s00792-003-0334-7

Bower SM (1987) Labyrinthuloides haliotidis n.sp (Protozoa, Labyrinthomorpha), a pathogenic parasite of small juvenile abalone in a British-Columbia mariculture facility. Can J Zool 65:19962007. https://doi.org/10.1139/z87-304

Bowman JS (2015) The relationship between sea ice bacterial community structure and biogeochemistry: a synthesis of current knowledge and known unknowns. Elem Sci Anth 3:000072. https:// doi.org/10.12952/journal.elementa.000072 
Bowman JS, Rasmussen S, Blom N et al (2012) Microbial community structure of Arctic multiyear sea ice and surface seawater by 454 sequencing of the 16S RNA gene. ISME J 6:11-20

Bowman JS, Berthiaume CT, Armbrust EV et al (2014) The genetic potential for key biogeochemical processes in Arctic frost flowers and young sea ice revealed by metagenomic analysis. FEMS Microbiol Ecol 89:376-387. https://doi.org/10.1111/1574-6941.12331

Brinkmeyer R, Knittel K, Jurgens J et al (2003) Diversity and structure of bacterial communities in Arctic versus Antarctic pack ice. Appl Environ Microbiol 69:6610-6619. https://doi.org/10.1128/ Aem.69.11.6610-6619.2003

Bronk DA, See JH, Bradley P et al (2007) DON as a source of bioavailable nitrogen for phytoplankton. Biogeosciences 4:283-296. https:// doi.org/10.5194/bg-4-283-2007

Brown MV, Bowman JP (2001) A molecular phylogenetic survey of sea-ice microbial communities (SIMCO). FEMS Microbiol Ecol 35:267-275. https://doi.org/10.1016/S0168-6496(01)00100-3

Bubnova EN, Nikitin DA (2017) Fungi in bottom sediments of the Barents and Kara Seas. Russ J Mar Biol 43:400-406. https://doi. org/10.1134/S1063074017050029

Campbell K, Mundy CJ, Barber DG et al (2014) Remote estimates of ice algae biomass and their response to environmental conditions during spring melt. Arctic 67:375-387. https://doi.org/10.14430/ $\operatorname{arctic} 4409$

Caron DA, Sanders RW, Lim EL et al (1993) Light-dependent phagotrophy in the freshwater mixotrophic chrysophyte Dinobryon cylindricum. Microb Ecol 25:93-111. https://doi.org/10.1007/BF00182132

Cavalieri DJ, Parkinson CL, Gloersen P et al (1999) Deriving long-term time series of sea ice cover from satellite passive-microwave multisensor data sets. J Geophys Res Oceans 104:15803-15814. https:// doi.org/10.1029/1999jc900081

Christman GD, Cottrell MT, Popp BN et al (2011) Abundance, diversity, and activity of ammonia-oxidizing prokaryotes in the Coastal Arctic Ocean in summer and winter. Appl Environ Microbiol 77:2026-2034. https://doi.org/10.1128/Aem.01907-10

Collins RE, Deming JW (2011) Abundant dissolved genetic material in Arctic sea ice Part II: viral dynamics during autumn freeze-up. Polar Biol 34:1831-1841. https://doi.org/10.1007/s00300-011-1008-z

Collins RE, Deming JW (2013) An inter-order horizontal gene transfer event enables the catabolism of compatible solutes by Colwellia psychrerythraea 34H. Extremophiles 17:601-610. https://doi. org/10.1007/s00792-013-0543-7

Collins RE, Rocap G, Deming JW (2010) Persistence of bacterial and archaeal communities in sea ice through an Arctic winter. Environ Microbiol 12:1828-1841. https://doi. org/10.1111/j.1462-2920.2010.02179.x

Comeau AM, Vincent WF, Bernier L et al (2016) Novel chytrid lineages dominate fungal sequences in diverse marine and freshwater habitats. Sci Rep 6:30120. https://doi.org/10.1038/srep30120

Cottrell MT, Kirchman DL (2009) Photoheterotrophic microbes in the Arctic Ocean in summer and winter. Appl Environ Microbiol 75:4958-4966. https://doi.org/10.1128/Aem.00117-09

Cottrell MT, Kirchman DL (2012) Virus genes in Arctic marine bacteria identified by metagenomic analysis. Aquat Microb Ecol 66:107116. https://doi.org/10.3354/ame01569

Damashek J, Pettie KP, Brown ZW et al (2017) Regional patterns in ammonia-oxidizing communities throughout Chukchi Sea waters from the Bering Strait to the Beaufort Sea. Aquat Microb Ecol 79:273-286. https://doi.org/10.3354/ame01834

De Corte D, Sintes E, Yokokawa T et al (2013) Comparison between MICRO-CARD-FISH and 16S rRNA gene clone libraries to assess the active versus total bacterial community in the coastal Arctic. Environ Microbiol Rep 5:272-281. https://doi. org/10.1111/1758-2229.12013
Delmont TO, Kiefl E, Kilinc O et al (2017) The global biogeography of amino acid variants within a single SAR 11 population is governed by natural selection. BioRxiv 170639. https://doi.org/10.1101/170639

Deming JW, Collins RE (2017) Sea ice as a habitat for bacteria, archaea and viruses. In: Thomas ND (ed) Sea ice. Wiley, New York, pp 326-351

Diez B, Bergman B, Pedros-Alio C et al (2012) High cyanobacterial nifH gene diversity in Arctic seawater and sea ice brine. Environ Microbiol Rep 4:360-366. https://doi.org/10.1111/j.1758-2229.2012.00343.x

Eicken H (2003) From the microscopic, to the macroscopic, to the regional scale: growth, microstructure and properties of sea ice. In: Thomas DN, Dieckmann GS (eds) Sea ice: an introduction to its physics, chemistry, biology and geology. Blackwell Sci, Oxford, pp 22-81

Eicken H, Gradinger R, Gaylord A et al (2005) Sediment transport by sea ice in the Chukchi and Beaufort Seas: increasing importance due to changing ice conditions? Deep-Sea Res II 52:3281-3302. https://doi.org/10.1016/j.dsr2.2005.10.006

Feller G, Gerday C (2003) Psychrophilic enzymes: hot topics in cold adaptation. Nat Rev Microbiol 1:200-208. https://doi.org/10.1038/ nrmicro773

Feng S, Powell SM, Wilson R et al (2014) Extensive gene acquisition in the extremely psychrophilic bacterial species Psychroflexus torquis and the link to sea-ice ecosystem specialism genome. Biol Evol 6:133-148. https://doi.org/10.1093/gbe/evt209

Fernández-Méndez M, Katlein C, Rabe B et al (2015) Photosynthetic production in the central Arctic Ocean during the record sea-ice minimum in 2012. Biogeosciences 12:3525-3549. https://doi. org/10.5194/bg-12-3525-2015

Fernández-Méndez M, Turk-Kubo KA, Buttigieg PL et al (2016) Diazotroph diversity in the sea ice, melt ponds, and surface waters of the Eurasian Basin of the Central Arctic Ocean. Front Microbiol 7:1884. https://doi.org/10.3389/fmicb.2016.01884

Firth E, Carpenter SD, Sorensen HL et al (2016) Bacterial use of choline to tolerate salinity shifts in sea-ice brines. Elem Sci Anth 4:000120. https://doi.org/10.12952/journal.elementa.000120

Fortunato CS, Huber JA (2016) Coupled RNA-SIP and metatranscriptomics of active chemolithoautotrophic communities at a deep-sea hydrothermal vent. ISME J 10:1925-1938. https://doi.org/10.1038/ ismej.2015.258

Gao DW, Huang XL, Tao Y (2016) A critical review of NanoSIMS in analysis of microbial metabolic activities at single-cell level. Crit Rev Biotechnol 36:884-890. https://doi.org/10.3109/07388551.20 15.1057550

Garrison DL, Close AR, Reimnitz E (1989) Algae concentrated by frazil ice - evidence from laboratory experiments and field measurements. Antarct Sci 1:313-316. https://doi.org/10.1017/ S0954102089000477

Gerdes B, Brinkmeyer R, Dieckmann G et al (2005) Influence of crude oil on changes of bacterial communities in Arctic sea-ice. FEMS Microbiol Ecol 53:129-139. https://doi.org/10.1016/j. femsee.2004.11.010

Gosselin M, Levasseur M, Wheeler PA et al (1997) New measurements of phytoplankton and ice algal production in the Arctic Ocean. Deep Sea Res II 44:1623-1644. https://doi.org/10.1016/ S0967-0645(97)00054-4

Gowing MM, Riggs BE, Garrison DL et al (2002) Large viruses in Ross Sea late autumn pack ice habitats. Mar Ecol Prog Ser 241:1-11. https://doi.org/10.3354/meps241001

Gradinger RR (2001) Adaptation of Arctic and Antarctic ice metazoa to their habitat. Zool-Anal Complex Sy 104:339-345. https://doi. org/10.1078/0944-2006-00039

Gradinger RR, Zhang Q (1997) Vertical distribution of bacteria in Arctic sea ice from the Barents and Laptev Seas. Polar Biol 17:448-454. https://doi.org/10.1007/s003000050139 
Gradinger RR, Kaufman MR, Bluhm BA (2009) Pivotal role of sea ice sediments in the seasonal development of near-shore Arctic fast ice biota. Mar Ecol Prog Ser 394:49-63. https://doi.org/10.3354/ meps 08320

Granskog M, Kaartokallio H, Kuosa H et al (2006) Sea ice in the Baltic Sea - a review. Estuar Coast Shelf Sci 70:145-160. https://doi. org/10.1016/j.ecss.2006.06.001

Grossmann S, Gleitz M (1993) Microbial responses to experimental sea-ice formation - implications for the establishment of Antarctic sea-ice communities. J Exp Mar Biol Ecol 173:273-289. https://doi. org/10.1016/0022-0981(93)90058-V

Grossmann S, Dieckmann GS (1994) Bacterial standing stock, activity, and carbon production during formation and growth of sea-ice in the Weddell Sea, Antarctica. Appl Environ Microbiol 60:2746-2753

Haecky P, Jonson S, Andersson A (1999) Influence of sea ice on the composition of the spring phytoplankton bloom in the northern Baltic Sea. Polar Biol 20:1-8. https://doi.org/10.1007/s003000050270

Hanic LA, Sekimoto S, Bates SS (2009) Oomycete and chytrid infections of the marine diatom Pseudo-nitzschia pungens (Bacillariophyceae) from Prince Edward Island, Canada. Botany 87:1096-1105. https:// doi.org/10.1139/B09-070

Hansen PJ (2011) The role of photosynthesis and food uptake for the growth of marine mixotrophic dinoflagellates. J Eukaryot Microbiol 58:203-214. https://doi.org/10.1111/j.1550-7408.2011.00537.x

Hassett BT, Gradinger RR (2016) Chytrids dominate arctic marine fungal communities. Environ Microbiol 18:2001-2009. https://doi. org/10.1111/1462-2920.13216

Hassett BT, Gradinger RR (2018) New species of saprobic Labyrinthulea (=Labyrinthulomycota) and the erection of a gen. nov to resolve molecular polyphyly within the Aplanochytrids. J Eukaryot Microbiol 65:475-483. https://doi.org/10.1111/jeu.12494

Hassett BT, Ducluzeau ALL, Collins RE et al (2017) Spatial distribution of aquatic marine fungi across the western Arctic and sub-arctic. Environ Microbiol 19:475-484. https://doi. org/10.1111/1462-2920.13371

Hatam I, Lange B, Beckers J et al (2016) Bacterial communities from Arctic seasonal sea ice are more compositionally variable than those from multi-year sea ice. ISME J 10:2543-2552. https://doi. org/10.1038/ismej.2016.4

Hegseth EN (1998) Primary production of the northern Barents Sea. Polar Res 17:113-123. https://doi.org/10.1111/j.1751-8369.1998. tb00266.x

Hobbie JE, Daley RJ, Jasper S (1977) Use of Nuclepore filters for counting bacteria by fluorescence microscopy. Appl Environ Microbiol 33:1225-1228

Holding JM, Duarte CM, Sanz-Martin M et al (2015) Temperature dependence of $\mathrm{CO}_{2}$-enhanced primary production in the European Arctic Ocean. Nat Clim Chang 5:1079-1082. https://doi. org/10.1038/Nclimate2768

Horner R, Alexander V (1972) Algal populations in Arctic sea ice investigation of heterotrophy. Limnol Oceanogr 17:454-458. https://doi.org/10.4319/lo.1972.17.3.0454

Horner R, Schrader GC (1982) Relative contributions of ice algae, phytoplankton, and benthic microalgae to primary production in nearshore regions of the Beaufort Sea. Arctic 35:485-503

Hoshiai T, Tanimura A, Watanabe K (edited by Hoshiai T) (1987) Ice algae as food of an Antarctic ice-associated copepod, Paralabidocera antarctica (IC Thompson). In: Proceedings of the NIPR Symposium on Polar Biology, Citeseer, pp 105-111

Hunt GL, Drinkwater KF, Arrigo K et al (2016) Advection in polar and sub-polar environments: impacts on high latitude marine ecosystems. Prog Oceanogr 149:40-81. https://doi.org/10.1016/j. pocean.2016.10.004

Jephcott TG, Alves-De-Souza C, Gleason FH et al (2016) Ecological impacts of parasitic chytrids, syndiniales and perkinsids on popula- tions of marine photosynthetic dinoflagellates. Fungal Ecol 19:4758. https://doi.org/10.1016/j.funeco.2015.03.007

Johnson TW, Sparrow FK (1961) Fungi in oceans and estuaries. Hafner Publishing, New York

Johnson SS, Zaikova E, Goerlitz DS et al (2017) Real-time DNA sequencing in the Antarctic dry valleys using the Oxford Nanopore sequencer. J Biomol Tech 28:2. https://doi.org/10.7171/ jbt.17-2801-009

Joli N, Monier A, Logares R et al (2017) Seasonal patterns in Arctic prasinophytes and inferred ecology of Bathycoccus unveiled in an Arctic winter metagenome. ISME J 11:1372-1385. https://doi. org/10.1038/ismej.2017.7

Junge K, Imhoff F, Staley T et al (2002) Phylogenetic diversity of numerically important arctic sea-ice bacteria cultured at subzero temperature. Microbial Ecol 43:315-328. https://doi.org/10.1007/ s00248-001-1026-4

Junge K, Eicken H, Deming JW (2004) Bacterial activity at -2 to -20 degrees $\mathrm{C}$ in Arctic wintertime sea ice. Appl Environ Microbiol 70:550-557. https://doi.org/10.1128/Aem.70.1.550-557.2004

Junge K, Cameron K, Nunn B (2019) Chapter 12 - diversity of psychrophilic bacteria in sea and glacier ice environments-insights through genomics, metagenomics, and proteomics approaches. In: Das S, Dash HR (eds) Microbial diversity in the genomic era. Academic Press, Cambridge, pp 197-216. https://doi.org/10.1016/ B978-0-12-814849-5.00012-5

Kaartokallio H (2001) Evidence for active microbial nitrogen transformations in sea ice (Gulf of Bothnia, Baltic Sea) in midwinter. Polar Biol 24:21-28. https://doi.org/10.1007/s003000000169

Kaartokallio H (2004) Food web components, and physical and chemical properties of Baltic Sea ice. Mar Ecol Prog Ser 273:49-63. https://doi.org/10.3354/meps273049

Kaartokallio H, Kuosa H, Thomas DN et al (2007) Biomass, composition and activity of organism assemblages along a salinity gradient in sea ice subjected to river discharge in the Baltic Sea. Polar Biol 30:183-197. https://doi.org/10.1007/s00300-006-0172-z

Kirchman DL, Hill V, Cottrell MT et al (2009) Standing stocks, production, and respiration of phytoplankton and heterotrophic bacteria in the western Arctic Ocean. Deep-Sea Res II 56:1237-1248. https:// doi.org/10.1016/j.dsr2.2008.10.018

Klimpel S, Palm HW, Busch MW et al (2006) Fish parasites in the Arctic deep-sea: poor diversity in pelagic fish species vs. heavy parasite load in a demersal fish. Deep-Sea Res I 53:1167-1181. https:// doi.org/10.1016/j.dsr.2006.05.009

Koh EY, Atamna-Ismaeel N, Martin A et al (2010) Proteorhodopsinbearing bacteria in Antarctic sea ice. Appl Environ Microbiol 76:5918-5925. https://doi.org/10.1128/Aem.00562-10

Koh EY, Phua W, Ryan KG (2011) Aerobic anoxygenic phototrophic bacteria in Antarctic sea ice and seawater. Env Microbiol Rep 3:710-716. https://doi.org/10.1111/j.1758-2229.2011.00286.x

Koh EY, Martin AR, McMinn A et al (2012) Recent advances and future perspectives in microbial phototrophy in Antarctic sea ice. Biology 1:542-556. https://doi.org/10.3390/biology1030542

Kohlmeyer J, Kohlmeyer E (2013) Marine mycology: the higher fungi. Elsevier, Amsterdam

Kottmeier ST, Sullivan CW (1987) Late winter primary production and bacterial production in sea ice and seawater west of the Antarctic Peninsula. Mar Ecol Prog Ser 36:287-298. https://doi.org/10.3354/ meps036287

Krembs C, Gradinger R, Spindler M (2000) Implications of brine channel geometry and surface area for the interaction of sympagic organisms in Arctic sea ice. J Exp Mar Biol Ecol 243:55-80. https://doi. org/10.1016/S0022-0981(99)00111-2

Krembs C, Eicken H, Junge K et al (2002a) High concentrations of exopolymeric substances in Arctic winter sea ice: implications for the polar ocean carbon cycle and cryoprotection of 
diatoms. Deep-Sea Res I 49:2163-2181. https://doi.org/10.1016/ S0967-0637(02)00122-X

Krembs C, Tuschling K, von Juterzenka K (2002b) The topography of the ice-water interface - its influence on the colonization of sea ice by algae. Polar Biol 25:106-117. https://doi.org/10.1007/ s003000100318

Krembs C, Eicken H, Deming JW (2011) Exopolymer alteration of physical properties of sea ice and implications for ice habitability and biogeochemistry in a warmer Arctic. Proc Natl Acad Sci USA 108:3653-3658. https://doi.org/10.1073/pnas.1100701108

Küpper FC, Peters AF, Shewring DM et al (2016) Arctic marine phytobenthos of northern Baffin Island. J Phycol 52:532-549. https://doi. org/10.1111/jpy.12417

Laamanen M (1996) Cyanoprokaryotes in the Baltic Sea ice and winter plankton. Algological Studies/Archiv für Hydrobiologie, Supplement Volumes 83:423-433

Lange BA, Katlein C, Nicolaus M et al (2016) Sea ice algae chlorophyll a concentrations derived from under-ice spectral radiation profiling platforms. J Geophys Res Oceans 121:8511-8534. https://doi. org/10.1002/2016jc011991

Lepelletier F, Karpov SA, Alacid E et al (2014) Dinomyces arenysensis gen. et sp nov (Rhizophydiales, Dinomycetaceae fam. nov.), a chytrid infecting marine dinoflagellates. Protist 165:230-244. https:// doi.org/10.1016/j.protis.2014.02.004

Leu E, Wiktor J, Søreide JE et al (2010) Increased irradiance reduces food quality of sea ice algae. Mar Ecol Prog Ser 411:49-60. https:// doi.org/10.3354/meps08647

Lewin J, Hellebust JA (1976) Heterotrophic nutrition of marine pennate diatom Nitzschia angularis var affinis. Mar Biol 36:313-320. https://doi.org/10.1007/Bf00389192

Lincoln BJ, Rippeth TP, Simpson JH (2016) Surface mixed layer deepening through wind shear alignment in a seasonally stratified shallow sea. J Geophys Res Oceans 121:6021-6034. https://doi. org/10.1002/2015jc011382

Lizotte MP (2003) The microbiology of sea ice. In: Thomas DN, Dieckmann GS (eds) Sea ice: an introduction to its physics, chemistry, biology and geology. Blackwell Sci, Oxford, pp 184-210

Luhtanen AM, Eronen-Rasimus E, Oksanen HM et al (2018) The first known virus isolates from Antarctic sea ice have complex infection patterns. Fems Microbiol Ecol 94:fiy028. https://doi.org/10.1093/ femsec/fiy028

Lytle VI, Ackley SF (1996) Heat flux through sea ice in the western Weddell Sea: convective and conductive transfer processes. J Geophys Res Oceans 101:8853-8868. https://doi. org/10.1029/95jc03675

Majaneva M, Blomster J, Müller S et al (2017) Sea-ice eukaryotes of the Gulf of Finland, Baltic Sea, and evidence for herbivory on weakly shade-adapted ice algae. Eur J Protistol 57:1-15. https://doi. org/10.1016/j.ejop.2016.10.005

Maranger R, Bird DF, Juniper SK (1994) Viral and bacterial dynamics in Arctic sea-ice during the spring algal bloom near Resolute, Nwt, Canada. Mar Ecol Prog Ser 111:121-127. https://doi.org/10.3354/ meps111121

Maslanik J, Stroeve J, Fowler C et al (2011) Distribution and trends in Arctic sea ice age through spring 2011. Geophys Res Lett 38:L13502. https://doi.org/10.1029/2011gl047735

Mclean N, Porter D (1982) The yellow-spot disease of Tritonia diomedea Bergh, 1894 (Mollusca, Gastropoda, Nudibranchia) - encapsulation of the thraustochytriaceous parasite by host amebocytes. J Parasitol 68:243-252. https://doi.org/10.2307/3281182

McKie-Krisberg ZM, Sanders RW (2014) Phagotrophy by the picoeukaryotic green alga Micromonas: implications for Arctic Oceans. ISME J 8:1953-1961. https://doi.org/10.1038/ismej.2014.16

Meier WN, Hovelsrud GK, van Oort BEH et al (2014) Arctic sea ice in transformation: a review of recent observed changes and impacts on biology and human activity. Rev Geophys 52:185-217. https://doi. org/10.1002/2013rg000431

Meiners K, Fehling J, Granskog MA et al (2002) Abundance, biomass and composition of biota in Baltic sea ice and underlying water (March 2000). Polar Biol 25:761-770. https://doi.org/10.1007/ s00300-002-0403-x

Miller LA, Fripiat F, Else BGT et al (2015) Methods for biogeochemical studies of sea ice: the state of the art, caveats, and recommendations. Elem Sci Anth 3:000038. https://doi.org/10.12952/journal. elementa.000038

Mock T, Gradinger RR (1999) Determination of Arctic ice algal production with a new in situ incubation technique. Mar Ecol Prog Ser 177:15-26. https://doi.org/10.3354/meps 177015

Mock T, Dieckmann GS, Haas C et al (2002) Micro-optodes in sea ice: a new approach to investigate oxygen dynamics during sea ice formation. Aquat Microb Ecol 29:297-306. https://doi.org/10.3354/ ame029297

Moline MA, Karnovsky NJ, Brown Z et al (2008) High latitude changes in ice dynamics and their impact on polar marine ecosystems. Ann N Y Acad Sci 1134:267-319. https://doi.org/10.1196/annals.1439.010

Moorthi S, Caron DA, Gast RJ et al (2009) Mixotrophy: a widespread and important ecological strategy for planktonic and sea-ice nanoflagellates in the Ross Sea, Antarctica. Aquat Microb Ecol 54:269277. https://doi.org/10.3354/ame01276

Naganuma T, Kimura H, Karimoto R et al (2006) Abundance of planktonic thraustochytrids and bacteria and the concentration of particulate ATP in the Greenland and Norwegian Seas. Polar Biosci 20:37-45

Nguyen D, Maranger R, Balague V et al (2015) Winter diversity and expression of proteorhodopsin genes in a polar ocean. ISME J 9:1835-1845. https://doi.org/10.1038/ismej.2015.1

Nichols D, Bowman J, Sanderson K et al (1999) Developments with Antarctic microorganisms: culture collections, bioactivity screening, taxonomy, PUFA production and cold-adapted enzymes. Curr Opin Biotechnol 10:240-246. https://doi.org/10.1016/ S0958-1669(99)80042-1

Niemi A, Michel C, Hille K et al (2011) Protist assemblages in winter sea ice: setting the stage for the spring ice algal bloom. Polar Biol 34:1803-1817. https://doi.org/10.1007/s00300-011-1059-1

Nierychlo M, Nielsen JL, Nielsen PH (2016) Studies of the ecophysiology of single cells in microbial communities by (quantitative) microautoradiography and fluorescence in situ hybridization (MAR-FISH). In: McGenity TJ, Timmis KN, Nogales B (eds) Hydrocarbon and lipid microbiology protocols: ultrastructure and imaging. Springer, Berlin, pp 115-130. https:// doi.org/10.1007/8623_2015_66

Nikrad MP, Cottrell MT, Kirchman DL (2012) Abundance and singlecell activity of heterotrophic bacterial groups in the Western Arctic Ocean in summer and winter. Appl Environ Microbiol 78:24022409. https://doi.org/10.1128/Aem.07130-11

Orsi W, Biddle JF, Edgcomb V (2013) Deep sequencing of subseafloor eukaryotic rRNA reveals active fungi across marine subsurface provinces. PLoS One 8:e56335. https://doi.org/10.1371/journal. pone. 0056335

Oziel L, Neukermans G, Ardyna M et al (2017) Role for Atlantic inflows and sea ice loss on shifting phytoplankton blooms in the Barents Sea. J Geophys Res Oceans 122:5121-5139. https://doi. org/10.1002/2016jc012582

Palmisano AC, Sullivan CW (1983) Sea ice microbial communities (SIMCO) - distribution, abundance, and primary production of ice microalgae in McMurdo Sound, Antarctica in 1980. Polar Biol 2:171-177. https://doi.org/10.1007/Bf00448967

Parker BC, Bold HC, Deason TR (1961) Facultative heterotrophy in some chlorococcacean algae. Science 133:761-763. https://doi. org/10.1126/science.133.3455.761 
Pernthaler A, Pernthaler J, Amann R (2002) Fluorescence in situ hybridization and catalyzed reporter deposition for the identification of marine bacteria. Appl Environ Microbiol 68:3094-3101. https://doi. org/10.1128/Aem.68.6.3094-3101.2002

Perovich D, Richter-Menge J, Polashenski C et al (2014) Sea ice mass balance observations from the North Pole Environmental Observatory. Geophys Res Lett 41:2019-2025. https://doi. org/10.1002/2014g1059356

Petri R, Imhoff JF (2001) Genetic analysis of sea-ice bacterial communities of the Western Baltic Sea using an improved double gradient method. Polar Biol 24:252-257. https://doi.org/10.1007/ s003000000205

Petrich C, Eicken H (2010) Growth, structure and properties of sea ice. In: Thomas DN, Dieckmann SD (eds) Sea ice, 2nd edn. Wiley, Oxford, pp 23-77

Picard KT (2017) Coastal marine habitats harbor novel early-diverging fungal diversity. Fungal Ecol 25:1-13. https://doi.org/10.1016/j. funeco.2016.10.006

Piiparinen J, Kuosa H, Rintala JM (2010) Winter-time ecology in the Bothnian Bay, Baltic Sea: nutrients and algae in fast ice. Polar Biol 33:1445-1461. https://doi.org/10.1007/s00300-010-0771-6

Piwosz K, Wiktor JM, Niemi A et al (2013) Mesoscale distribution and functional diversity of picoeukaryotes in the first-year sea ice of the Canadian Arctic. ISME J 7:1461-1471. https://doi.org/10.1038/ ismej.2013.39

Polglase JL (1980) A preliminary report on the thraustochytrid(s) and labyrinthulid(s) associated with a pathological condition in the Lesser octopus Eledone cirrhosa. Bot Mar 23:699-706. https://doi. org/10.1515/botm-1980-1106

Poulin M, Daugbjerg N, Gradinger RR et al (2011) The pan-Arctic biodiversity of marine pelagic and sea-ice unicellular eukaryotes: a first-attempt assessment. Mar Biodivers 41:13-28. https://doi. org/10.1007/s12526-010-0058-8

Rahimian H (1998) Pathology and morphology of Ichthyophonus hoferi in naturally infected fishes off the Swedish west coast. Dis Aquat Org 34:109-123. https://doi.org/10.3354/dao034109

Rämä T, Norden J, Davey ML et al (2014) Fungi ahoy! Diversity on marine wooden substrata in the high North. Fungal Ecol 8:46-58. https://doi.org/10.1016/j.funeco.2013.12.002

Rämä T, Hassett BT, Bubnova E (2017) Arctic marine fungi: from filaments and flagella to operational taxonomic units and beyond. Bot Mar 60:433-452. https://doi.org/10.1515/bot-2016-0104

Rapp JZ, Fernández-Méndez M, Bienhold C et al (2018) Effects of icealgal aggregate export on the connectivity of bacterial communities in the central Arctic Ocean. Front Microbiol 9:1035. https://doi. org/10.3389/fmicb.2018.01035

Reimnitz E, Clayton JR, Kempema EW et al (1993) Interaction of rising frazil with suspended particles - tank experiments with applications to nature. Cold Reg Sci Technol 21:117-135. https://doi. org/10.1016/0165-232x(93)90002-P

Riedel A, Michel C, Gosselin M et al (2008) Winter-spring dynamics in sea-ice carbon cycling in the coastal Arctic Ocean. J Mar Syst 74:918-932. https://doi.org/10.1016/j.jmarsys.2008.01.003

Rintala JM, Piiparinen J, Blomster J et al (2014) Fast direct melting of brackish sea-ice samples results in biologically more accurate results than slow buffered melting. Polar Biol 37:1811-1822. https://doi.org/10.1007/s00300-014-1563-1

Ruiz-González C, Gali M, Sintes E et al (2012) Sunlight effects on the osmotrophic uptake of DMSP-Sulfur and leucine by polar phytoplankton. PLoS One 7:45545. https://doi.org/10.1371/journal. pone. 0045545

Rysgaard S, Glud RN (2004) Anaerobic N-2 production in Arctic sea ice. Limnol Oceanogr 49:86-94. https://doi.org/10.4319/ 10.2004.49.1.0086
Rysgaard S, Glud RN, Sejr MK et al (2008) Denitrification activity and oxygen dynamics in Arctic sea ice. Polar Biol 31:527-537. https:// doi.org/10.1007/s00300-007-0384-x

Sanders RW (1991) Mixotrophic protists in marine and freshwater ecosystems. J Protozool 38:76-81. https://doi. org/10.1111/j.1550-7408.1991.tb04805.x

Sanders RW, Gast RJ (2012) Bacterivory by phototrophic picoplankton and nanoplankton in Arctic waters. FEMS Microbiol Ecol 82:242253. https://doi.org/10.1111/j.1574-6941.2011.01253.x

Scholz B, Küpper FC, Vyverman W et al (2017a) Chytridiomycosis of marine diatoms-The role of stress physiology and resistance in parasite-host recognition and accumulation of defense molecules. Mar Drugs 15:26. https://doi.org/10.3390/md15020026

Scholz B, Vyverman W, Küpper FC et al (2017b) Effects of environmental parameters on chytrid infection prevalence of four marine diatoms: a laboratory case study. Bot Mar 60:419-431. https://doi. org/10.1515/bot-2016-0105

Secretariat of Arctic Council (2017) State of the arctic marine biodiversity report. Conservation of Arctic Flora and Fauna, Fairbanks

Sencilo A, Luhtanen AM, Saarijarvi M et al (2015) Cold-active bacteriophages from the Baltic Sea ice have diverse genomes and virushost interactions. Environ Microbiol 17:3628-3641. https://doi. org/10.1111/1462-2920.12611

Serreze MC, Francis JA (2006) The Arctic amplification debate. Clim Chang 76:241-264. https://doi.org/10.1007/s10584-005-9017-y

Sherr EB, Sherr BF, Fessenden L (1997) Heterotrophic protists in the Central Arctic Ocean. Deep-Sea Res II 44:1665-1673. https://doi. org/10.1016/S0967-0645(97)00050-7

Shields JD (1990) Rhizophydium littoreum on the eggs of Cancer anthonyi - parasite or saprobe. Biol Bull 179:201-206. https://doi. org/10.2307/1541770

Singh SM, Tsuji M, Gawas-Sakhalker P et al (2016) Bird feather fungi from Svalbard. Arctic Polar Biol 39:523-532. https://doi. org/10.1007/s00300-015-1804-y

Sipler RE, Gong D, Baer SE et al (2017) Preliminary estimates of the contribution of Arctic nitrogen fixation to the global nitrogen budget. Limnol Oceanogr Lett 2:159-166. https://doi.org/10.1002/ lol2.10046

Søgaard DH, Kristensen M, Rysgaard S et al (2010) Autotrophic and heterotrophic activity in Arctic first-year sea ice: seasonal study from Malene Bight, SW Greenland. Mar Ecol Prog Ser 419:31-45. https://doi.org/10.3354/meps08845

Søreide JE, Leu E, Berge J et al (2010) Timing of blooms, algal food quality and Calanus glacialis reproduction and growth in a changing Arctic. Glob Chang Biol 16:3154-3163. https://doi. org/10.1111/j.1365-2486.2010.02175.x

Stoecker DK, Weigel AC, Stockwell DA et al (2014) Microzooplankton: abundance, biomass and contribution to chlorophyll in the Eastern Bering Sea in summer. Deep-Sea Res II 109:134-144. https://doi. org/10.1016/j.dsr2.2013.09.007

Stroeve JC, Markus T, Boisvert L et al (2014) Changes in Arctic melt season and implications for sea ice loss. Geophys Res Lett 41:12161225. https://doi.org/10.1002/2013g1058951

Syvertsen EE (1991) Ice algae in the Barents Sea - types of assemblages, origin, fate and role in the ice-edge phytoplankton bloom. Polar Res 10:277-287. https://doi.org/10.1111/j.1751-8369.1991. tb00653.x

Taylor GT, Sullivan CW (2008) Vitamin B-12 and cobalt cycling among diatoms and bacteria in Antarctic sea ice microbial communities. Limnol Oceanogr 53:1862-1877. https://doi.org/10.4319/ 10.2008.53.5.1862

Tedesco L, Vichi M, Haapala J et al (2010) A dynamic biologically active layer for numerical studies of the sea ice ecosystem. Ocean Model 35:89-104. https://doi.org/10.1016/j.ocemod.2010.06.008 
Tedesco L, Miettunen E, An BW et al (2017) Long-term mesoscale variability of modelled sea-ice primary production in the northern Baltic Sea. Elem Sci Anth 5:29. https://doi.org/10.1525/elementa.223

Terrado R, Medrinal E, Dasilva C et al (2011) Protist community composition during spring in an Arctic flaw lead polynya. Polar Biol 34:1901-1914. https://doi.org/10.1007/s00300-011-1039-5

Toole JM, Timmermans ML, Perovich DK et al (2010) Influences of the ocean surface mixed layer and thermohaline stratification on Arctic sea ice in the central Canada Basin. J Geophys Res Oceans 115. https://doi.org/10.1029/2009jc005660

Tremblay JE, Anderson LG, Matrai P et al (2015) Global and regional drivers of nutrient supply, primary production and $\mathrm{CO}_{2}$ drawdown in the changing Arctic Ocean. Prog Oceanogr 139:171-196. https:// doi.org/10.1016/j.pocean.2015.08.009

Trenerry LJ, McMinn A, Ryan KG (2002) In situ oxygen microelectrode measurements of bottom-ice algal production in McMurdo Sound, Antarctica. Polar Biol 25:72-80. https://doi.org/10.1007/ s003000100314

Ueda M, Nomura Y, Doi K et al (2015) Seasonal dynamics of culturable thraustochytrids (Labyrinthulomycetes, Stramenopiles) in estuarine and coastal waters. Aquat Microb Ecol 74:187-204. https://doi. org/10.3354/ame01736

Unrein F, Massana R, Alonso-Sáez L et al (2007) Significant yearround effect of small mixotrophic flagellates on bacterioplankton in an oligotrophic coastal system. Limnol Oceanogr 52:456-469. https://doi.org/10.4319/1o.2007.52.1.0456

Unrein F, Gasol JM, Not F et al (2014) Mixotrophic haptophytes are key bacterial grazers in oligotrophic coastal waters. ISME J 8:164176. https://doi.org/10.1038/ismej.2013.132

Vader A, Marquardt M, Meshram AR et al (2015) Key Arctic phototrophs are widespread in the polar night. Polar Biol 38:13-21. https://doi.org/10.1007/s00300-014-1570-2

Vader A, Laughinghouse HD, Griffiths C et al (2018) Proton-pumping rhodopsins are abundantly expressed by microbial eukaryotes in a high-Arctic fjord. Environ Microbiol 20:890-902. https://doi. org/10.1111/1462-2920.14035

Vancoppenolle M, Tedesco L (2017) Numerical models of sea ice biogeochemistry. In: Thomas DN (ed) Sea ice. Wiley, New York, pp 492-515

Voipio A (1981) The Baltic Sea. Elsevier, Amsterdam
Vonnahme TR, Devetter M, Zarsky JD et al (2016) Controls on microalgal community structures in cryoconite holes upon highArctic glaciers, Svalbard. Biogeosciences 13:659-674. https://doi. org/10.5194/bg-13-659-2016

Wassmann P, Slagstad D, Ellingsen I (2010) Primary production and climatic variability in the European sector of the Arctic Ocean prior to 2007: preliminary results. Polar Biol 33:1641-1650. https://doi. org/10.1007/s00300-010-0839-3

Wassmann P, Duarte CM, Agusti S et al (2011) Footprints of climate change in the Arctic marine ecosystem. Glob Chang Biol 17:12351249. https://doi.org/10.1111/j.1365-2486.2010.02311.x

Weeks WF, Ackley SF (1986) The growth, structure, and properties of sea ice. In: Untersteiner $\mathrm{N}$ (ed) The geophysics of sea ice. Springer US, Boston, pp 9-164. https://doi. org/10.1007/978-1-4899-5352-0_2

Weissenberger J, Grossmann S (1998) Experimental formation of sea ice: importance of water circulation and wave action for incorporation of phytoplankton and bacteria. Polar Biol 20:178-188. https:// doi.org/10.1007/s003000050294

Wells LE, Deming JW (2006a) Characterization of a cold-active bacteriophage on two psychrophilic marine hosts. Aquat Microb Ecol 45:15-29. https://doi.org/10.3354/ame045015

Wells LE, Deming JW (2006b) Modelled and measured dynamics of viruses in Arctic winter sea-ice brines. Environ Microbiol 8:11151121. https://doi.org/10.1111/j.1462-2920.2005.00984.x

Werner I, Auel H (2004) Environmental conditions and overwintering strategies of planktonic metazoans in and below coastal fast ice in the Gulf of Finland (Baltic Sea). Sarsia 89:102-116. https://doi. org/10.1080/00364820410003504

Worby AP, Bush GM, Allison I (2001) Seasonal development of the sea-ice thickness distribution in East Antarctica: measurements from upward-looking sonar. Ann Glaciol 33:177-180. https://doi. org/10.3189/172756401781818167

Yergeau E, Michel C, Tremblay J et al (2017) Metagenomic survey of the taxonomic and functional microbial communities of seawater and sea ice from the Canadian Arctic. Sci Rep 7:42242. https://doi. org/10.1038/srep42242

Zhang Q, Gradinger R, Zhou QS (2003) Competition within the marine microalgae over the polar dark period in the Greenland Sea of high Arctic. Acta Oceanol Sin 22:233-242

Open Access This chapter is licensed under the terms of the Creative Commons Attribution 4.0 International License (http://creativecommons. org/licenses/by/4.0/), which permits use, sharing, adaptation, distribution and reproduction in any medium or format, as long as you give appropriate credit to the original author(s) and the source, provide a link to the Creative Commons license and indicate if changes were made.

The images or other third party material in this chapter are included in the chapter's Creative Commons license, unless indicated otherwise in a credit line to the material. If material is not included in the chapter's Creative Commons license and your intended use is not permitted by statutory regulation or exceeds the permitted use, you will need to obtain permission directly from the copyright holder. 